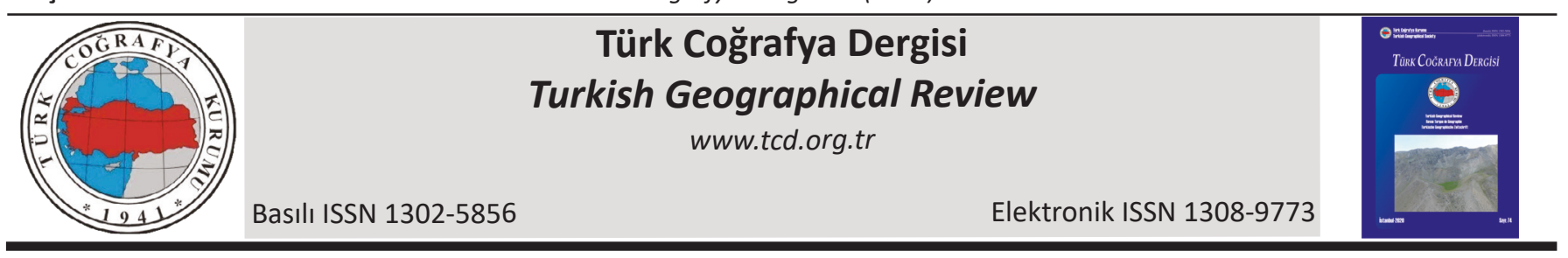

\title{
Van'ın Edremit ilçesinde turizmin gelişimi: Rezilyans ve değişim
}

\section{The development of tourism in Edremit Province of Van: Resilience and change}

\section{Emine Cihangir ${ }^{\mathrm{a}}$ (D) $\quad$ Mehmet Şeremet*b (1)}

${ }^{a}$ Van Yüzüncü Yıl Üniversitesi, Turizm Fakültesi, Turizm Işletmeciliği Bölümü, Van.

${ }^{b}$ Van Yüzüncü Yıl Üniversitesi, Denizcilik Fakültesi, Deniz Ulaştırma İşletme Mühendisliği Bölümü, Van

ORCID: E.C. 0000-0001-8514-6655; M.Ş. 0000-0003-3416-4794

\section{BILGI / INFO}

Geliş/Received: 09.12.2019

Kabul/Accepted: 29.04 .2020

\section{Anahtar Kelimeler:}

Rezilyans

Turizm

Van

Edremit

Planlama

\section{Keywords:}

Resilience

Tourism

Van

Edremit

Planning

*Sorumlu yazar/Corresponding author: (M. Şeremet)mseremet@hotmail.co.uk

DOI: $10.17211 /$ tcd. 657017

\section{Atif/Citation:}

Cihangir, E. ve Şeremet, M. (2020). Van'ın Edremit ilçesinde turizmin gelişimi: Rezilyans ve değişim. Türk Coğrafya Dergisi (74), 47-59.

DOI:10.17211/tcd.657017.

\section{ÖZ / ABSTRACT}

Turizm hem gelişmekte olan hem de gelişmiş ülkeler için önemli bir istihdam yaratma ve katma değer üretme kaynağıdır. Gelişmekte olan ülkeler açısından turizmin gelişimi özellikle bölgesel ekonomik, sosyal ve kültürel dengesizliklerin ortadan kaldırılması noktasında da önemlidir. Ancak, gelişim ve kalkınma sürecinin doğrusal bir ivme ile devam etmesi çoğu zaman beklenemez. Bunun sosyal, politik, doğal ve çevresel nedenleri olabilmektedir. Bu araştrrmada, Turizm Coğrafyası araştırmalarında son yıllarda kullanılan ve beklenilmeyen durumlara karşı yerel toplumların geliştirmeleri beklenilen "rezilyans" teorisi ile turizm ilişkisi ele alınmaktadır. Bu çerçevede, daha önce turizmin gelişmesi noktasında farklı olumsuz (deprem, terör, ekonomik istikrarsızlık) gibi durumlara maruz kalmış olan Van'ın Edremit ilçesi örnek alan olarak seçilmiştir. Araştırma'da veriler nitel araştırma stratejisine bağlı olarak yüz yüze mülakatlar aracılı̆̆ıyla toplanmıştı. Çalışma sonucunda, yerel sektör temsilcilerinin Edremit ilçesindeki turizmin gelişimi ile değişimi sürecinde adaptasyonları eleştirel bir boyutta değerlendirilmiştir. Çalışma, özellikle rezilyans teorinin turizmle ilişkisinin yerel aktörler aracılığıyla ortaya konulması noktasında literatürde önemli bir boşluğu dolduracağı düşünülmektedir. Çalışma sonucunda, yerel işletmelerin ve sektör temsilcilerinin değişen sürece yönelik bakış açılarının olumlu olduğu, turistik ürünlerin çeşitlendirilmesi ve yenilikçi bir perspektifle sunulması noktasında fikir birliği içerisinde olduklarını ortaya çıkmaktadır. Bununla birlikte, işbirliği, birlikte hareket etme, katılımcı yönetim gibi zorlukların ise rezilyans bir turizm toplumu olma noktasında zayıf yönlerinin olduğu görülmektedir

Tourism is an important source of employment and value added for developed and developing countries alike. The development of tourism is particularly important in the elimination of regional economic, social and cultural imbalances in developing countries. However, development and advancement cannot be expected to continue with a linear acceleration. This may dependent on social, political, natural and environmental reasons. In this study, the relationship between tourism and the resilience theory which is used in tourism geography researches in recent years and which is expected to be developed by local communities against unexpected situations is thoroughly discussed. In this context, the Edremit province of Van, which has been exposed to few disturbance situations (earthquake, terrorism, economic instability) at the point of development of tourism, has been selected as a case area. The data were collected through face-to-face interviews based on the qualitative research strategy. As a result of this study, adaptations of local sector representatives in the development and change of tourism in Edremit province were critically evaluated. The study is considered to fill an important gap in the literature, especially in terms of revealing the relationship between the resilience theory and tourism through local actors. As a result of this study, it has been seen that local enterprises and sector representatives have positive views on the changing process and they all agree on diversification of tourism products and presenting them with an innovative perspective. However, it is seen that difficulties such as cooperation, acting together, participatory management have weaknesses in terms of being a resilient tourism community.

\section{Giriş}

Turizm, BM'in 2030 Sürdürülebilir Kalkınma Hedefleri çerçevesinde birçok alt amacın hedeflerine ulaşması için önemli ekonomik sektörlerden bir tanesidir (Boluk vd. 2019). Turizm sektörü UNWTO'nun 2019 istatistiklerine göre 100 milyon'dan daha fazla istihdam ve milyon dolarlık katma değer üretme kap- asitesiyle gelişmekte olan ülkeler için önemli bir yere sahiptir Bu anlamda, bölgesel kalkınma ve bölgesel kalkınma dengesizliklerinin azaltılmasında önemli bir rolü bulunmaktadır. Sürekli bir gelişim ve büyüme hedefi ile hareket eden turizm için 'sürdürülebilirlik' kavramı önemli bir yere sahiptir. Ancak, sürdürü- 
lebilir kalkınma ve turizm arasındaki ilişki oldukça karmaşık ve çoğu zamanda zıt yönlü olabilmektedir (Ruiz-Ballesteros, 2011). Bu çelişkinin giderilebilmesi noktasında, Ruiz-Ballesteros'un (2011: 656) vurguladığı üzere gerçek manada sürdürülebilir kalkınmanın gerçekleşebilmesi için özellikle rezilyans teorisi önemlidir. Sürdürülebilir Kalkınma çoğu zaman hem çevresel anlamda hem de insanların refah düzeylerinin iyileştirilmesi anlamında sürekli bir genişlemeyi hedeflemektedir. Ancak, bununla birlikte, özellikle gelişmekte olan ülkelerde yoksulluk ve diğer sosyal sorunlar nedeniyle doğal çevrenin kullanımında aşırı ve yanlış tüketim ekolojik denge üzerinde yoğun bir baskı oluşturabilmektedir (Adger, 2000). Bugün, özellikle yerel düzeyde önemsediğimiz sistemlerin esnekliğini bastırmakla tehdit eden dört ana krizle -çevresel, enerji, ekonomik ve eşitlik-ile karşı karşıyayız. Uluslararası sürdürülebilirlik çabalarının bu krizleri engelleme konusundaki başarısızlığı, toplum düzeyinde rezilyans (esneklik) geliştirme çabalarına -sadece iklim değişikliği ve altyapı üzerine değil tüm konular ve sistemler üzerinde çalışan- her zamankinden daha çok ihtiyaç duyulduğu anlamına gelmektedir (Lerch,2017: 2). Rezilyans sürdürülebilir kalkınmanın tam aksine toplumların esneklik kabiliyetlerini artrarak değişime ve beklenmedik durumlara yönelik daha sürdürülebilir çözümler üretebilmektedir (Perrings, 1998: 221). Bunun temel nedeni ise, rezilyans hem değişime yönelik adaptasyon kapasitenin artırılmasını hem de kalkınma sürecinin kesintiye uğramadan devam etmesini öngörmektedir ve özellikle toplumların değişim süreci ve deneyimleri (bilgi, beceri ve öğrenme) ile dönüşümlerini anlamlandırabilmek için önemli bir kavramdır (Herman, 2015: 103). Rezilyans, yerel toplulukların geleceğin ekonomik, sosyal, çevresel ve iklim zorluklarını aşmasına yardımcı olmak için gereken planlama ve tasarım stratejileri için bir şemsiye terim haline gelmiştir. (Beckett \& Raeder, 2017:1) Bu noktada, Weichselgartner ve Kelman (2014) tarafindan da ifade edildiği gibi özellikle mekânsal planlama sürecinde sürdürülebilirlikten hassasiyete doğru bir yer değiştirme sürecinde esneklik kavramı bir araç olarak karşımıza çıkmaktadır. Bu kavram, bilim, uygulama ve politika alanları arasında da önemli bir bağlant sağlama aracı olarak da görülmektedir (Farrell ve Twining-Ward, 2004; Becken, 2013).

Farrell ve Twining-Ward (2004) tarafindan turizmdeki sürdürülebilirlik araştırmalarının karmaşık yapılar ve sistemleri de (ekosistem, doğal afetler, ekonomik krizler ve politik değişimler gibi) içermesi gerektiği vurgulanmaktadır. Bu bağlamda, turizmin de önemli bir ekonomik sektör olarak yeniden kavramsallaştrrma sürecinde özellikle doğal ve sosyal ortamdaki doğrusal olmayan (non-linear) değişim ve dönüşümlere karşı bir esneklik mekanizmasıyla birlikte yeni stratejiler geliştirilmesi beklenmektedir (Farrell \& TwiningWard, 2004; Luthe ve Wyss, 2014). Bu çerçevede turizm araştırmalarında bu perspektif giderek önem kazanmaktadır (Biggs, 2011; Biggs vd. 2012; Becken, 2013; Strickland-Munro vd. 2010). Uluslararası literatürde, bu yeni paradigma çerçevesinde belirsizlik ve beklenmeyen durumlara yönelik turizm araştırmalarının yapıldığı görülmektedir. Ancak Türkiye'deki sürdürülebilirlik perspektifinde birçok turizm çaIışmasında sadece potansiyelin ortaya konulması ve bu potansiyele yönelik deneyimlerin araştırıldığı görülmektedir. Turizmin sektörünün değişen sürece yönelik nasıl bir esneklik mekanizması geliştirdiği ve bunu nasıl deneyimlediği noktasında literatürde önemli bir eksiklik bulunmaktadır Bu çerçevede Türkiye'de yürütülen bu araştırmada seçilen sahanın sahip olduğu sosyo-ekolojik (dağ ekosistemi, deprem, iklim değişimi, terör sorunları) ve kültürel sistemler nedeniyle, belirsizlik ve değişimlere açık bir noktada bulunması nedeniyle önem arz etmektedir. Bu çalışmanın temel amacı, yerel işletmeci ve sektör temsilcilerinin görüşleri aracılığıyla bu bölgedeki turizm gelişimini, değişimini ve yaşanan süreçlere yönelik esneklik durumlarını eleştirel bir bakış açısıyla değerlendirerek, sahadaki bilgiyi esneklik/adaptasyon ('resilience') tabanlı teorik bir perspektif üzerine inşa etmeyi hedeflemektedir. Bu çerçeve de şu araştrrma sorularına yanıt aranmaktadır:

1-Edremit ilçesindeki turizm trendlerinde nasıl bir değişim gerçekleşmiştir?

2-Sektörün Edremit ilçesindeki değişen turizm trendlerine yönelik nasıl bir adaptasyonu söz konusudur?

\section{3-Sektörün turizm politikalarına yönelik beklentileri nelerdir?}

4-Sektör, Edremit ilçesindeki turizm odaklı gelişim noktasında mekânsal planlama konusunda ne düşünmektedir?

Araştırma sorularını yanıtlamak amacıyla nitel araştırma tasarımı tercih edilmiştir. Bu araştırma ile belirtilen konuların en iyi bir şekilde araştrılabileceği destinasyonlardan biri olarak Van'ın Edremit ilçesi seçilmiştir. Bu sahanın seçilmesinin en önemli nedenlerinden biri Edremit'in çok yüksek düzeyde turizm potansiyeline sahip olmasına rağmen alan yazında yer alan bazı akademik veya kurumsal raporlarda (Aşur, 2017; VANTSO, 2018; Van Ili Çevre Durum Raporu, 2006 ) ilçenin tarihi ve doğal yönleri ile ilgili bilgiler yer almış olmasına rağmen turizm potansiyeline yönelik spesifik akademik çalışmanın yapılmamış olmasıdır.

Çalışmada, araştırma sahasıyla ilgili daha detaylı bilgilere geçilmeden öncelikle araştırmanın dayanağını oluşturan rezilyans teorisi ile ilgili teorik ve kavramsal çerçeve sunulacak daha sonra teorinin turizm konusu kapsamında anlamsal olarak kavramsallaştırımasına çalışılacaktır. Bu noktada, araştırma da aynı zamanda turizme yönelik planlama, değişim ve adaptasyon kavramlarının birlikte ele alınması düşünülmektedir.

\section{Teorik ve Kavramsal Çerçeve}

\subsection{Teorik Çerçeve: Rezilyans (Esneklik Kapasitesi)}

15. yy. ortalarında Rezilyans kavramı ilk olarak psikolojide kullanılmıştır. "Resilience' kavramı Türkçeye çevrilirken farklı kavramlar ile ifade edilmektedir. Kavram, Türkçe alan yazında "yılmazlık, esneklik, dayanıklıık veya psikolojik olarak sağlamıı" olarak farklı kavramlar ile ifade edilebilmektedir (Seçkin ve Hasanoğlu, 2016). Ancak, kelimenin orijinali Fransızca "yaylanma" anlamına gelmektedir. Kelime anlamıyla esneklik ve olumsuz bir duruma uyum sağlama şeklinde yorumlanabilmektedir. Rezilyans kavramının farklı alanlarda üzerinde anlaşmaya varılmış tek bir tanımı bulunmamaktadır. Kavram, Holling vd. (1994) tarafindan bir sistemin, davranışını kontrol eden değişkenleri ve süreçleri değiştirerek yapısının değiştirilmesinden önce bertaraf edilebilecek olumsuzluğun büyüklüğü şeklinde ifade edilmektedir. Yine, Berkes ve Folk (1994) tarafindan ise bir sistemin ortaya çıkan endişeleri tolere edebilme becerisi olarak tanımlanmaktadır (s.4). Genel bir tanım verecek olursak 
Perrings (1998: 221) tarafindan şu şekilde ifade edilmektedir: "esneklik bir sistemin strese ve şoklara karşı dayanma kabiliyetinin belirsiz bir dünyada devam etme becerisinin bir ölçüsüdür". Rezilyans kavramının ilerleyen süreçte sosyoloji biliminde sıklıkla kullanılmaya başlandığı ve "rezilyans" teorisi olarak özellikle toplumsal ve mekânsal ilişkileri araştıran çalışmalarda yaygın olarak yer aldığı görülmektedir.

Günümüzde rezilyans, psikoloji başta olmakta üzere Sosyoloji, Arkeoloji, Ekoloji ve Coğrafya'da yaygın olarak kullanılan bir teori haline gelmiştir (Weichselgartner ve Kelman, 2014; Redman \& Kinzig, 2003, Walker vd. 2006; Adger; 2000; Wilson, 2013). Ancak, Weichselgartner ve Kelman (2014: 251) tarafindan da vurgulandığı üzere, kavram coğrafya bilimi içerisinde diğer disiplinlerin aksine daha bütünsel bir yaklaşım çerçevesinde ele alınmaktadır. Bu bütünsel yaklaşım hem doğal hem yapay (üretilen) hem de sosyal ortamı içerisine eşit bir dengede ele alacak şekilde temsil edilmektedir (Berkes ve Folke, 1998). Bu bağlamda, Berkes ve Ross (2013), rezilyans teorinin iki temel boyutu bulunduğunu ifade etmektedir. Boyutlardan bir tanesinin sistem yaklaşımını temel alan sosyo-ekolojik ve doğal çevre odaklı olduğunu vurgulamaktadırlar. Araştırmacılar bu birinci boyutun daha fazla gelişme göstererek daha çok doğal çevre değişimleri ve bunlarda ortaya çıkan çeşitli konulara -doğal afetler, çevresel değişimler, doğal kaynakların tüketilmesi gibiyönelik olarak da değişik firsatlar ve çözümler üretmesi gerektiğine vurgu yapmaktadır. Ancak sistem yaklaşımı boyutu, coğrafya biliminin bazı düşünce okulları tarafindan neo-liberalizm vurgusu yaptığı için eleştirilmektedir (bknz. Welsh, 2013). Ruiz-Ballesteros (2014: 655) sosyo-ekolojik sistemin üç temel özelliği olduğunu ve bunun da dirençli bir sistem için önemli bir yeterlilik oluşturduğunu vurgulamaktadır. Bu çerçevede ilk özelliği doğasında bir yenilikçilik içermesi, dolayısıyla sistemin herhangi bir şekilde çökmesi veya çökme eğiliminde olması durumunda alternatif bir sistem oluşturma kapasitesinin bulunmasıdır. İkincisi ise, dış değişkenlerin etkisini tamamen kabul etmeden önce bir sistemin kendi kaderini kontrol etme derecesini belirleyen iç kontrol mekanizmalarını geliştirerek adapte olabilmesidir. Son olarak ise insan hegemonyasına vurgu yaparak bu tür sistemlerin uygulanabilirliğinin ancak onu yöneten bireylerin ve grupların yeterlilikleri ve onların öğrenme becerileri ile ilgili olduğunu söylemektedir. Bu kapsamda, bu üç sistemin birlikte rezilyans için önemli bir kapasite oluşturduğunu ifade etmektedir.

Rezilyans teorisi doğal ve sosyal ortam arasındaki ilişkiye gönderme yapmakla birlikte, Maclean vd. (2004) tarafindan da ifade edildiği üzere, sosyal ortamın bileşenlerinin araştırılmasının daha az irdelendiği görülmektedir. Bu nedenle bu eksikliğin giderilmesi için araştırmacılar tarafindan (Tobin, 1999; Adger; 2000) "sosyal rezilyans" kavramının ortaya atıldığı bilinmektedir (Berkes ve Ross, 2013; Maclean vd. 2014; Bec vd. 2016). Berkes ve Ross (2003: 7) tarafindan rezilyansın iki temel boyut üzerinden açıklandığı vurgulanmışt. İkinci boyutun psikolojik temelli akıl ve ruh sağlığını temel alan sosyal bir boyut olduğunu ifade etmektedirler. Bu yaklaşım ise toplumsal rezilyans yaklaşımını oluşturmaktadır. Araştırmacılar tarafindan da ifade edildiği üzere iki boyutun da ortak özelliği bir sistemin (örneğin bireyler, topluluklar, geniş toplumlar, dayanışmalar, sosyo-ekolojik ve ekolojik sistemler) değişime karşı gösterdiği adaptasyon kapasitesidir. Rezilyans, bir sistemin -bir aile, bir toplum, bir ülke veya Dünya'nın biyosferleri gibi- kısa-dönemli bozulmalar veya olumsuzluklar ile başa çıkma ve temel karakterini kaybetmeden uzun vadeli değişikliklere uyum sağlama yeteneğidir. (Lerch, 2017: 1). Toplumun rezilyansı bir topluluğun, olumsuz durumlara cevap vermek, bunlara dayanmak ve bunlardan kurtulmak için mevcut kaynakları kullanma yeteneğinin sürekli bir ölçüsü olarak ifade edilebilir. Daha rezilant olmak isteyen topluluklar, kırılganlıklarını değerlendirmekte ve her türlü tehlikeye karşı duyarlılıklarını ve maruz kalmalarını azaltmak için eylem planları yapmaktadırlar (Beckett \& Raeder, 2017:1). Toplumların herhangi bir olumsuz duruma karşı göstermiş olduğu refleks, o toplumun rezilyans bir toplum mu yoksa kaderci bir toplum mu olduğunu gösteren en önemli göstergelerden bir tanesidir (Özden, 2012). Stokholm Rezilyans Araştırma Merkezi (2019) tarafindan ise sosyal rezilyans, "insan topluluklarının çevresel değişim veya sosyal, ekonomik veya politik sorunlar gibi streslere dayanma ve bunlardan kurtulma yeteneği", şeklinde tanımlanmaktadır. Bu durumda, sosyo-ekolojik rezilyans çoğu zaman bir değişim öngörüsüne ve kapasitesine sahipken, toplumsal rezilyans da ise daha çok bir direnci içermektedir. Örneğin, bir balıkçı kasabasındaki ekolojik kaynaklarda meydana gelen bir değişim bunun sonucunda ortaya çıkan ekonomik bir çöküş, bazen daha farklı ekonomik firsatların -turizm gibi-oluşumuna neden olabilmektedir (Walker vd. 2004).

Toplumların yaşadığı olumsuzluklara karşı geliştirmiş oldukları refleks ve baş etme kapasitesi onların ne ölçüde adapte olabilmeyi başarabildikleri ve değişim odaklı olduklarıyla ilgilidir. İnsan öğesinin ön plana çıktığını bu çerçevede; insanın refahı ve mutluluğu için olabilecek eşitsizliklerin giderilmesi, işbirlikçi yönetimlerin oluşturulması, toplum bilincinin oluşturulması ve geliştirilmesi, mekân ve insan etkileşimine insan değerlerinin ve inançlarının entegre edilmesi, sosyal bağlantıların artırılması, ekonomik çeşitlilik, liderlik, altyapı ve gelecek perspektifini oluşturmak gibi önemli noktaları içermektedir. (Berkes ve Ross, 2003: 7). Bu anlamda, rezilyans bireysel yani kişisel özelliklerden daha çok adaptasyonun, herhangi sistemin prensipleri veya ilkelerine doğru bir değişim geçirdiğini göstermektedir. Maclean vd. $(2014 ; 149)$ tarafindan yapılmış olan örnek olay araştrrmalar sonucunda, sistemin toplumsal bir sistem olması durumunda "esnek bir yapının" sahip olması gereken 6 temel özelliğinin olduğu ifade edilmiştir. Bu özellikler; bilgi, beceri ve öğrenme; toplumsal dayanışma; mekaninsan etkileşimi; toplumsal altyapı; yenilikçi ve yaratıcı ekonomi; geniş katılımlı yönetimdir. Stockholm rezilyans araştrrma merkezi ise sosyo-ekolojik rezilyans için bu stratejilerin sayısını 7 olarak belirlenmiştir. Benzer şekilde katılımcı yönetim, sosyo-ekolojik sistemdeki çok parçalılığın farkındalığı, çeşitlikçi ve yenilikçi ekonomi, toplumsal öğrenme, toplumsal dayanışma gibi stratejiler ortak olarak kullanılırken, kendilerinin ise yavaş değişkenleri kontrol etme ve ceza gibi yeni bir yöntemi de ortaya koydukları görülmektedir.

Sonuç olarak, rezilyans veya esneklik teorisi daha çok toplumda meydana gelen sosyal (göç, yoksulluk, izolasyon, eşitsizlikler, hassasiyet gibi), ekonomik (kriz, çöküş, dalgalanma vb.), çevresel (iklim değişimi, depremler, tsunamiler, ve hortumlar vb.) veya enerji sorunlarına karşı esneklik reflekslerini ortaya koymayı amaçlamaktadır (Lambert vd. 2010; Folke, 2006; Biggs, 2011; Hung vd. 2016; Paidakaki \& Moulaert, 2017; Munt, 2012; Leap, 2018, Lerch, D., 2017). Bu noktada geliştirilen çeşitli stra- 
tejilerden bir tanesi de eğitimdir (Sterling, 2010), çünkü sosyoekolojik sistemler sürekli bir gelişme içerisinde olduğu için yeni bilgi ve beceri kazanımı özellikle toplumsal esneklik için önemlidir. Bu anlamda, öncellikle toplumdaki değişim ve dönüşüme yönelik uyum konuları araştırılmış olmasına rağmen, eğitim son yıllarda turizm alanındaki adaptasyon, direnç veya uyumlulukta çok fazla sosyal, ekonomik ve ekolojik değişim geçiren toplumlar için önemli bir boyuttur. Bu anlamda, toplumsal rezilyans ve turizm arasında da önemli bir ilişki bulunmaktadır (Amir vd. 2015)

\subsection{Kavramsal Çerçeve: Turizm ve Rezilyans}

Toplumsal ve sosyo-ekolojik rezilyans yaklaşımlarıyla turizmin ilişkisi literatürde son yıllarda popüler olan konuların başında gelmektedir (Cheer ve Lew, 2017; Luthe, \& Wyss, 2014; RuizBallesteros, 2011). Turizm çalışmalarında rezilyans konusu farklı boyutlarıyla ele alınmaktadır. Turizm rezilyansı kavramının nasıl tanımlandığını bu noktada vurgulamak gereklidir. Tyrrell ve Johnston $(2008$; 16) tarafindan "sosyal, ekonomik ya da ekolojik sistemlerin turizm kaynaklı stresten kurtulma yeteneği" olarak tanımlanmaktadır. Daha önce ifade edildiği gibi özellikle sürdürülebilir kalkınma teorisi sürekli bir ekonomik odaklı gelişimi öngördüğü için toplumlar ve yerel halk üzerinde bir baskı oluşturmaktadır. Buna karşın, turizm araştırmalarında rezilyans teorileri aracılığıyla daha çok doğal afetlerin etkileri, ekolojik ve kültürel kaynakların tüketilmesi ve aşırı kullanımı, korunan alanlar, yerel topluluklar, turizmin topluma etkisi gibi konuların araştırıldığı görülmektedir (Becken, 2013; Luthe \& Wyss, 2014; Strickland-Munro vd. 2010; Ruiz-Ballesteros, 2011; Tsao \& Ni, 2016; Coghlan\&Prideaux, 2009; Espiner \& Becken, 2014; Amir vd. 2015; Bec vd. 2016; Lambert vd. 2010). Bu araşttrmaların birçoğunun Büyük Okyanus kıyılarına yakın olan tropikal iklim bölgelerinde özellikle gelişmekte olan toplumların temel geçim kaynakları olan turizm faaliyetlerinin değişen doğal ve sosyokültürel olaylarla nasıl değiştiği ve yerel halkın bu değişime nasıl adapte olabildiklerine yönelik gerçekleştirildiği görülmektedir. Ancak, literatürde Türkiye odaklı çalışmaların yeteri kadar yer almadığı görülmektedir. Bu çalışmanın bu anlamda alan yazında önemli bir boşluğu dolduracağı düşünülmektedir.

Turizm içerisinde rezilyans kavramı, yerel halkın doğayla girdikleri yakın ilişki içerisinde edinmiş oldukları bilgi ve beceriyi kullanmalarından gelen yetenekleri nedeniyle sosyoekolojik adaptasyon olarak da yaygın bir şekilde kullanılmaktadır (RuizBallesteros, 2011). Öğrenme ve beceri geliştirme doğal ortam içerisinde özellikle kırsal kesimde yaşayan küçük topluluklar için daha yaygın bir durumdur (Holladay ve Powell, 2013). Turizm ile esneklik teorilerini açıklayan birçok çalışma özellikle sosyoekolojik ve toplumsal rezilyansa yönelik çeşitli örnek olay araştırmalarına odaklanmaktadır. Teorik boyuttaki araştırmalar arasındaki en önemlilerinden birisi Lew (2014) tarafindan Turizm Coğrafyaları (Tourism Geographies) dergisinde yayınlanan çalışmadır ve turizm çalışmalarına yönelik teori geliştirme noktasında önemli bir katkı sunmuştur. Annals of Tourism Research gibi turizm teorilerinin tartşııldığı önemli dergilerde de benzer çalışmalar yayınlanmıştır (Orchiston vd. 2016; Dahles ve Susilowati, 2015). Bu çerçevede, bir coğrafyacı olan Lew (2014: 1418) tarafindan geliştirilen Sosyal, Değişim ve Rezilyans (SCR) (Social, Change and Resillence / Sosyal, Değişim ve Rezilyans) modeli çerçevesinde turizmin rezilyans kavramıyla ilişkisi çeşitli boyutlarıyla kavramsallaştırılmıştır. Model yaşanan rahatsızıı derecesine ve katılan turizm aktörlerinin statüsü (girişimciler ile ortak kamu çıkarları) ölçeğine bağlı olarak dört genelleştirilmiş turizm bağlamını kavramsallaştırmaktadır. Modelde turizm üretiminin aracı olarak düşünülebilecek özel girişimcilerin rezilyans meselelerini ele almada, destinasyon pazarlama şirketleri ve yerel veya bölgesel hükümetler gibi daha fazla kamu veya kolektif çıkar elde etmekten daha farklı bir odağa sahip olduğunu varsaymaktadır. Modelde, Lew 4 tip tanımlanmıştır. Lew, "Tip 1" ve "Tip 2" yaklaşımını özel girişimci ve topluluk turizmi perspektifi çerçevesinde kavramsallaştırırken, bu iki tarzın daha çok düşük değişim ve uzun vadeli planlama süreçleriyle birlikte bertaraf edilebilecek (tesislerin kademeli aşınma ve yıpranma entropisinden öngörülen bozulma ile ilişkili kalıcı değişimleri yönetmesi) ile sosyal, ekonomik veya ekolojik konular (su tasarrufu, fosil yakıt tüketimi ve kültürel kaynakların korunması gibi) olduğunu vurgulamaktadır. Diğer taraftan "Tip 3" ve "Tip 4" ise daha çok ani değişimle karşılaşılması durumunu ifade etmektedir. Bu iki model arasında özellikle tip 3 yaklaşımı turizm girişimcisi için aniden ortaya çıkan (deprem, sel vs.) veya bir süreç içerisinde gerçekleşen (politik krizler, sosyal krizleri vs.) olumsuz durum karşısında almaları gereken önlemleri ve gösterebilecekleri refleksleri ortaya koymaktadır. Bu şok ortamında özel şahıs veya turizm işletmesi için en büyük endişe altyapı, ekonomik, politik veya diğer aksaklıklar nedeniyle başlıca turistik cazibe kaynaklarına veya birincil turizm pazarlarına erişimin kaybıdır. Tip 4 ise kamuoyu ölçeğinde aniden ortaya çıkan (büyük doğal ve insan felaketleri ve krizler) ve turizm sektörünün çok ötesinde etkiler yaratan durumlar karşısında almaları gereken önlemleri ve hazırlık planlamasını ortaya koymaktadır. Buna karşın geliştirilebilecek yaklaşımları ise "öğrenme" ve "çeşitlenme" olarak öngörülmektedir. Bu çerçevede özellikle öğrenme ile bu tarz ani değişimlerden ders çıkarmak için bu yaşanan olumsuz durumlara karşı halkın ve ziyaretçilerin öğrenmelerine destek olabileceklerini ifade etmektedir. Bunun da özellikle ziyaretçilerin ve yerel halkın bu tarz hassasiyetlere karşı öğrenmelerinin özellikle turistik çekicilik merkezleri aracılığıyla gerçekleştirileceği ifade edilmektedir. Ayrıca, özellikle gönüllülük projeleri ile gerekli duyuşsal öğrenmelerin sağlanabileceği ifade edilmektedir. Sektörün ise çeşitlenmeyi hem insanı kaynağı anlamında hem de turistik ürün çeşitliliği noktasında gerçekleştirilebileceğini vurgulamaktadır. Örneğin, Becker (2013) tarafindan Yeni Zelanda üzerine yapılan bir araştrrmada iklim şartlarının turizmin alt sistemlerini nasıl etkilediği ve buna karşın tur operatörlerin hangi esneklik mekanizmalarını geliştirdiğini ortaya koymaktadır. Coghlan ve Prideaux (2009) tarafindan Avustralya'da yapılan bir araştırmada iklim değişimi sonucunda mercan resiflerine yönelik yapılan turizm faaliyetlerinin değişen iklim koşulları sonucunda turist deneyimlerini nasıl etkilediğine yönelik çeşitli bulgular ortaya koymaktadır. Strickland-Munro vd. (2010) tarafindan rezilyans ve karmaşık sistemler aracılığıyla korunan alanlardaki turizm faaliyetlerinin yerel topluluklara etkisi araştırılmıştır. Yöntemsel olarak ortaya çıkan bu yaklaşım daha çok belirsizlikler ve karmaşık yapıların ve sistemlerin çözümlenmesi noktasında etkili bir araç olduğunu göstermektedir.

Turizm ve rezilyans arasındaki ilişkiye yönelik araştırma konularının son yıllarda ekolojik ve doğal sistem konularından yerel dinamiklerin oluşturduğu sistemlere doğru kaydığı görülmektedir. Bunun temel nedenleri olarak turizm sektöründe yerelleşme ve farklılaşmanın son yıllarda büyük önem kazanması, 
turizmin hem kırılgan hem de kolay adaptasyon gösteren bir yapıya sahip olması sayılabilir. Sektörün bu şekilde bir yapıya sahip olması turizmcilerin hem işini zorlaştrrmakta hem de kendilerine çeşitli firsatlar yaratabilmektedir. Kitlesel turizmin aktiviteleri nedeniyle hızlı bir kentleşme süreci yaşayan mekânlarda durum biraz daha farklıdır. Böyle bir durumda, turizm faaliyetlerinin kentsel yaşam ortamlarında gerçekleşmesi nedeniyle değişim ve dönüşüme karşı yerel halkın dışında sektöründe nasıl bir refleks ile kapasite geliştirdiği önemli bir husustur. Bu araştırma da özellikle bu boyut ele alınmaktadır. Bu nedenle, rezilyans kavramı bu çalışmada daha çok yerel halk düzeyinde değil de sektörün reflekslerini etkileyen değişkenlerin açıklanması noktasında kavramsallaştrılacaktır. Bu nokta da özellikle vurgulanması gereken önemli bir husus değişim ve adaptasyon sürecini zorunlu kılan faktörlerin açıklanmasıdır.

\section{Araștırmanın Yöntemi}

\subsection{Araştırma Sahasının Coğrafi, Tarihsel ve Kültürel Özellikleri}

Van İlinin 13 ilçesinden biri olan Edremit Van İ Merkezi'ne bağ|ı bucak iken 1990 yılında ilçe olmuştur. İlçenin kuzeyinde Van Gölü, güneyinde Gürpınar ve Gevaş İlçeleri, batısında Van Gölü ve Gevaş İlçesi ve Doğusunda Van Merkez köyleri ile Gürpınar İlçesi yer almaktadır. İlçenin yüzölçümü $600 \mathrm{~km}^{2}$ olup, deniz seviyesinden 1846 metre yükseklikte ve $38^{\circ} 25^{\prime} 27^{\prime \prime} \mathrm{N}$, $43^{\circ} 15^{\prime} 22^{\prime \prime}$ E koordinatlarına sahiptir. Van-Bitlis karayolu üzerinde yer alan ilçe Van Merkezine 18 km mesafede olup il Merkezi sınırından başlayan ve Gevaş İlçesi sınırına kadar Van Gölü kıyı şeridi boyunca devam eden bir yerleşime sahiptir. İlçenin 2018 yılı nüfusu 125 884'tür. (Türkiye Nüfusu il ilçe Mahalle Köy Nüfusları, 2018) (Şekil 1).

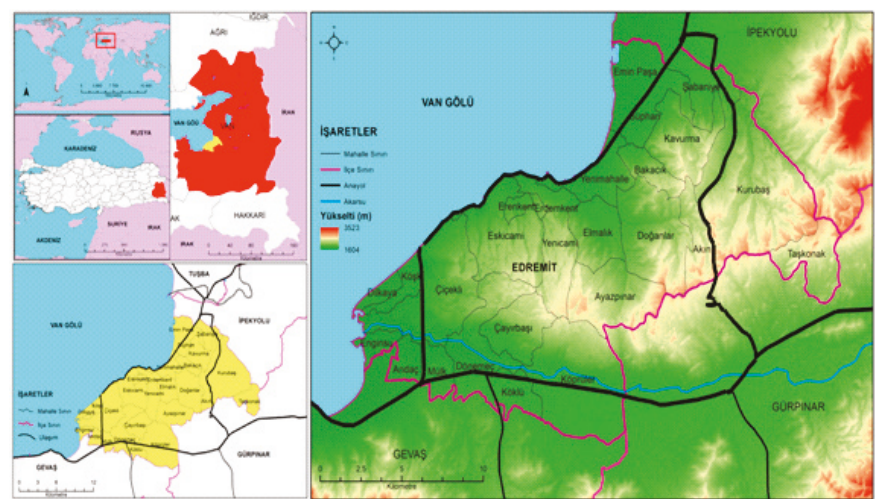

Şekil 1. Edremit ilçesinin lokasyon ve mahallerinin yükselti modeli ile ilişkisinin gösterimi

Figure 1. A view of the location of Edremit province and its neighbourhoods with an elevation model

Edremit ilçesi lokasyon olarak Van kenti için önemli bir rekreasyon mekânı durumundadır. Bunun en önemli nedenlerinden bir tanesi ilçenin bulunduğu sahilin falezsiz bir yapıya ve Van Gölü'nün güney ve güneybat istikametinde uzanan $5 \mathrm{~km}$ uzunluğunda ve yer yer 1-2 km genişliğinde güzel bir sahile sahip olmasıdır (Şekil 2).

İlçede bulunan yeme-içme mekânları da ilçenin önemli bir çekicilik merkezi olmasında önemli bir özelliğe sahiptir. Özellikle 2013 yılından sonra kent merkezinde yer alan geleneksel Van Kahvalt Salonlarının ve çeşitli kafe-restoran işletmelerinin bölgede, ağırlıklı olarak da sahil kesiminde işletme açmaya başlamaları hem Edremit'te yerleşik olarak yaşayanların hem de
Van'ın diğer ilçelerinde yaşayanların bölgeyi günün her saatinde yoğun olarak ziyaret etmesine neden olmuştur. Bu yoğun ilgi bölgede daha önce yer almayan işletmelerin ve girişimcilerin dikkatini fazlasıyla çekmiş ve yeme-içme mekânlarının sayısının ve çeşitliliğinin hızla artmasına yol açmıştır. Edremit ilçesi sahil bandında aynı zamanda kentin önemli konaklama tesisleri de yer almaktadır. Bu sahada hâlihazırda bir tane 5 yıldızlı, iki tane 4 yıldızıı (araştırmanın yapıldığı dönemde bu sayı sadece bir taneydi), bir tane Butik Otel ve bir tane de Bed and Breakfast (BB) olmak üzere toplamda 5 adet konaklama işletmesi bulunmaktadır .

İlçe Van ilinin önemli Turizm çekiciliklerinin de bulunduğu alanlara çok yakın bir mesafede yer almaktadır. Akdamar kilisesinin yer adlığı Van-Gevaş ilçesinde bulunan Akdamar adasına 32 km uzaklıktadır. Yine Gevaş'ta yer alan Selçuklu Mezarlarına ve Halime Hatun Kümbetine gidiş yolu güzergâhı üzerinde yer almaktadır. Van ili ve ilçeleri, 1990'lı yıllarda her yıl neredeyse 1 milyon -yabancı ve yerli- turist sayısına ulaşmaktaydı. Ancak geçmişte Avrupalı turistlerinde yoğun ilgi gösterdiği kent yaşanan bazı olumsuz süreçler nedeniyle uzun yıllar turizm talebi konusunda duraksama yaşamıştir. Bununla birlikte, son yıllarda 9 geçmişte sahip olduğu turistik destinasyon özelliğini yeniden elde etmek isteyen kentin aktörleri (yöneticiler, sektör, STK vb. ) yoğun bir çaba içine girmiştir. Bu bağlamda Edremit Belediyesi tarafindan da eşzamanlı olarak İlçenin turizm altyapısının oluşturulmasına yönelik yoğun çaba sarf edilmiştir. Yürütülen çalışmalardan en önemlilerinden biri yeşil donatı alanlarının düzenlenmesine yönelik olarak sahil bandında günübirlik rekreasyon alanlarının yaratılmasıdır. Buna ek olarak ilk olarak Dilkaya höyüğü yakınında dizayn edilen halk plajı, daha sonra Kıyıcak mevkisine taşınarak özellikle çoğunluğu, İranlı turistlerden oluşan yabancı ziyaretçiler için de önemli bir çekim alanı haline gelmiştir(şekil 2).

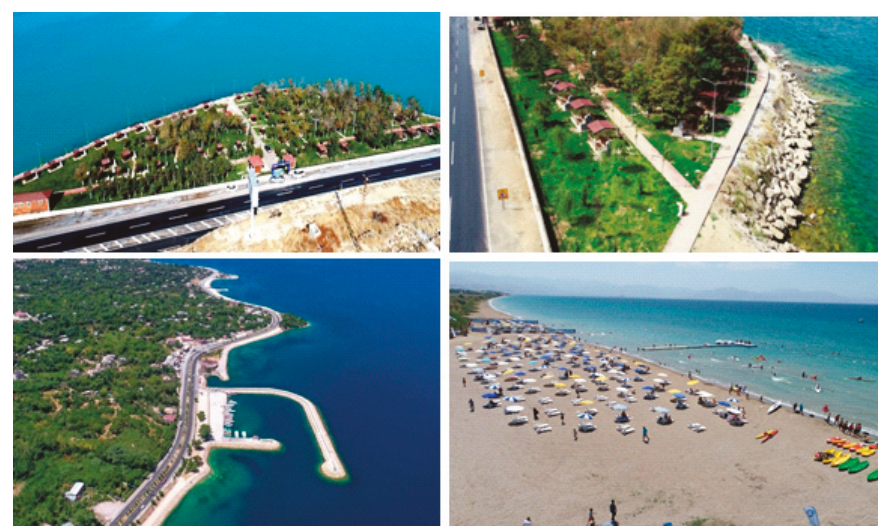

Şekil 2. Edremit ilçesinde yer alan günübirlik rekreasyon alanlarından bir görünüm

Figure 2. A view of daily recreational areas in Edremit Province

Bu çerçevede 2017 yılında başlatılan proje ile sahil bandının kent ile buluştuğu Edremit Kent Meydanı oluşturulmuştur. Meydan göl ile bütünleşik planlanmış özel yürüyüş yolları ve bağlantlı parkları ve fiziksel altyapısıyla ilçe için önemli bir rekraktif bir merkez haline dönüşmüştür (Şekil 3). Meydanda yer alan eski taş yapı yenilenerek hükümet konağı olarak hizmet vermeye başlamıştır. Hükümet konağının birinci kat ise çeşitli sergiler vb. gibi etkinlikler için kullanılan bir fuaye alanı olarak düzenlenmiştir. Kent meydanı hizmete girdiği 2018 yılı Temmuz ayından itibaren her yıl binlerce kişinin konserler ve etkinlikler için bir araya geldiği önemli bir sosyalleşme alanı olmuştur. 

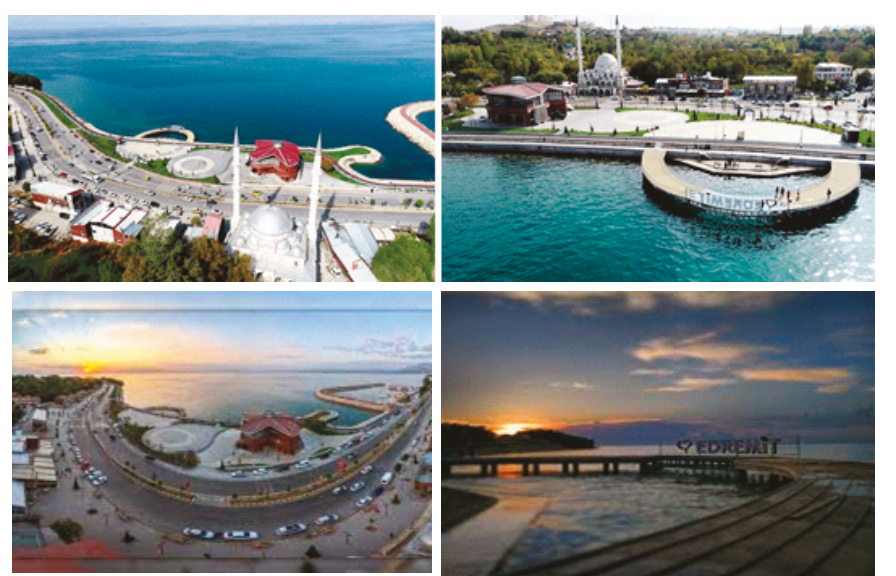

Şekil 3. Edremit kent meydanından bir görünüm

Figure 3. A view of Edremit's city centre

Edremit, Van kentinin 2011 yılında yaşadığı depremlerden bir tanesinin merkez üssü durumundaydı.dadır. Bu nedenle ilçede birçok bina ve ev hasar görmüştür. Van depremi sonrasında ilçenin hemen yüksek platoluk düzlüklerinde yer alan alanlara TOKi tarafindan deprem konutlarının yapılması ve deprem bakımında güvenli olması nedeniyle birçok devlet kurumunun da bu saha da binalar inşa etmeleri sonucunda hızlı bir kentleşme ve yoğun nüfuslanma sürecine girmiştir (Şekil 4).
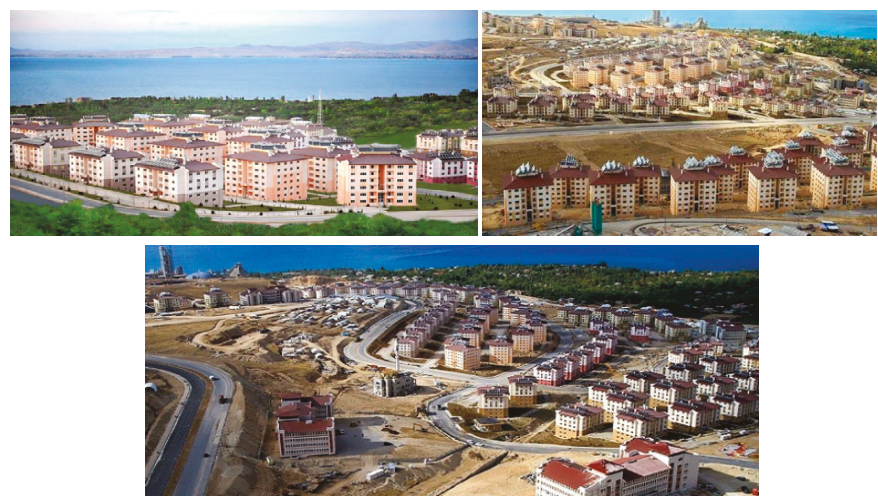

Şekil 4. Edremit'teki TOKi Toplu Konut Alanından Bir Görünüm Figure 4. A view of TOKi projects in Edremit province

Belediye, yoğun yapılaşma olan bu bölgede de rekreasyon alanlarının düzenlenmesini gerçekleştirmiştir. TOKi konutlarının bulunduğu sahaya yakın alanda kenti ve Edremit'i gören bir konumda bulunan Kız Kalesi restore edilerek bir manzara-seyir terası haline getirilmiştir (Şekil 5).
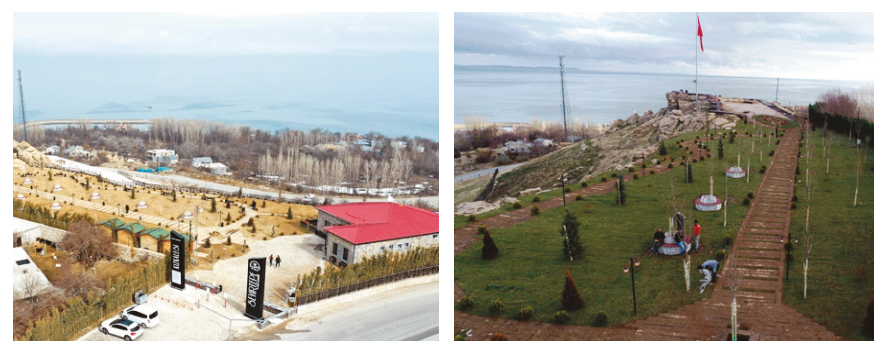

Şekil 5. Edremit "Kız Kalesinden" Bir Görünüm

Figure 5. A view of "Women Castle" in Edremit Province

Edremit geçmişin izlerini üzerinde taşımaktadır ve bugün halen daha çok küçük ve dar sokakları ile meyve bahçelerinin yer aldığı yavaş bir kent özelliğine sahiptir. Ancak, Çevre ve Şehircilik Bakanlığı tarafindan oluşturulan 1/100.000'lik çevre ve düzenleme planları incelendiğinde illçenin gelecekte tamamen yeme- içme ile günü birlik rekrasyonel alanların olduğu bir yerleşim merkezine dönüştürülmesine yönelik planlama yapıldığı görülmektedir. Bu çerçevede ilçede yer alan mevcut durumun değişime uğrayarak ileri ki süreçte yoğun yerleşim alanları olarak kullanılacağı tahmin edilmektedir. Bu anlamda, ilç̧enin özellikle Van depreminden sonra başlayan yapılaşma sürecinin turizm çekiciliklerinin artması ile daha da hızlanarak kentleşme sürecine girdiği söylenilebilir.

Diğer taraftan İlçenin Çiçekli beldesi ile sahil arasında kalan alan yer ise "ekoturizm" turizm alanı olarak planlanmaktadır. Bu alanın sahile yakın olan kesiminde ise Belediye tarafindan yaptırıIan "At Binicilik ve Eğitim Merkezi" ile "Karavan Park Yeri ve Kamping Alanı" ise İlçe ile Gevaş arasındaki Köşk Mahallesinde yer almaktadır (Şekil 6 ve 7). Karavan ve Kamp alanı 50 tane Karavan ve 100 tane çadır sığabilecek şekilde planlanmıştır. Bu planda Gevaş'ın güneyinde yer alan mekanlar ise sahil boyunca "Turizm Gelişim" alanları olarak planlandığı görülmektedir.

Diğer taraftan İlçenin Çiçekli beldesi ile sahil arasında kalan alan yer ise "ekoturizm" turizm alanı olarak planlanmaktadır. Bu alanın sahile yakın olan kesiminde ise Belediye tarafindan yaptırılan "At Binicilik ve Eğitim Merkezi" ile "Karavan Park Yeri ve Kamping Alanı" ise Illçe ile Gevaş arasındaki Köşk Mahallesinde yer almaktadır (Şekil 6 ve 7). Karavan ve Kamp alanı 50 tane Karavan ve 100 tane çadır sığabilecek şekilde planlanmıştır. Bu planda Gevaş'ın güneyinde yer alan mekanlar ise sahil boyunca "Turizm Gelişim" alanları olarak planlandığı görülmektedir.
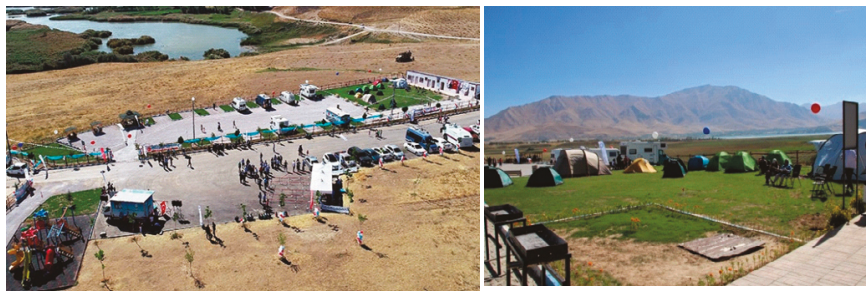

Şekil 6. Edremit'in Dilkaya Köyünde Bulunan "Karavan Park ve Kamping Alanından" Bir görünüm

Figure 6. A view of "Caravan Parking" and "Camping" areas in Dilkaya village.

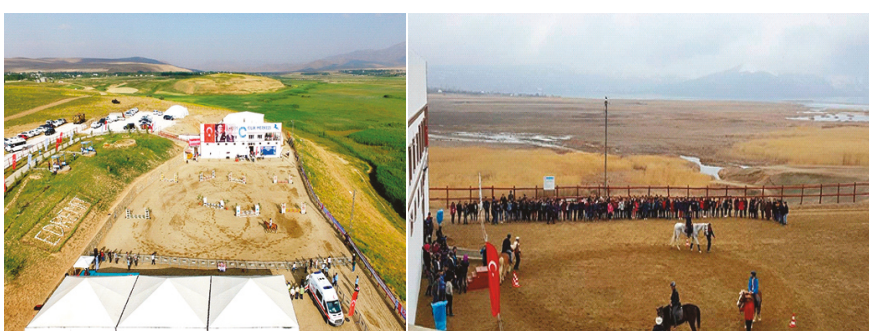

Şekil 7. Edremit "Olimpik Binicik Merkezinden" Bir Görünüm Figure 7. A view of "Olympic Horsing Centre" in Edremit Province

\section{Veri Toplama Yöntemi ve Analizi}

Araştırmada nitel araştırma dizaynına dayalı örnek olay çalışması tercih edilmiştir. Bu çerçevede saha da gözlemler ve nitel araştırma tekniklerinden bir tanesi olan mülakatlar aracılığıyla verilerin toplanması sağlanmıştır. Edremit ilçesinin Turizm Gelişimi ve Değişiminin Araştırılması için Kasım 2018- Ocak 2019 tarihleri arasında Van ilinde hizmet veren 6 (alt) ayrı Turizm ve Seyahat Acentesi ve Edremit ilçesinde bulunan 11 (on bir) yerel işletmeci (yeme-içme ve konaklama) ile birebir görüşme gerçekleştirilmiştir. Bununla birlikte, özellikle yerel yöneticiler ile 
de informal görüşmeler gerçekleştirilerek çeşitli planlama ve politikalara yönelik bilgiler edinilmiştir. Katılımcılara yöneltilen sorulara verilen cevaplar ışığında Edremit'in turizm gelişim ve değişimi rezilyans teori kapsamında değerlendirilmeye çalışılmıştır. Bunlardan ilki, acentelerin Edremit'e ilişkin genel olarak yaklaşımını görmek, diğeri ise acentelerin hangi konularda ortak hangi konularda farklı düşündüklerini tespit etmek olmuştur. Araşttrmacılar tarafindan saha ile ilgili çeşitli etnografik gözlemler gerçekleştirmiştir.

Yorumlayıcı perspektifte, toplanılan veriler içerik analizi ile incelenmiştir. Elde edilen bulgular çerçevesinde tematik ve kavramsal çıkarımlar yapılmıştır. Analiz sonuçlarının sunulmasında Yerel İşletmeciler "Yi" ile Seyahat Acentaları ise "SA" ile kodlanarak bulguları destekleyici olarak, yorumlarına yer verilmiştir.

\section{Bulgular}

\subsection{Yerel Esnaf ve Seyahat Acentaları ile Yapılan Görüş- melere İlişkin Bulgular}

Edremit İlçesinde turizm deneyimi olan 11 yerel işletmeci ve 6 seyahat acentası ile yapılan görüşmelerde; Rezilyans Teorisi kapsamında Van'da dönemsel olarak yaşanan terör olayları, 2011 yılında yaşanan deprem felaketi ve son yıllarda tüm dünyayı dolayısıyla ülkemizi etkileyen ekonomik kriz ve bölgesel jeopolitik sorunların (Türkiye-İran ilişkileri, Suriye ve Irak'tan bölgeye yönelik göçler) yansımaları sonucunda turizm potansiyelinde meydana gelen değişime adaptasyonları ve geliştirdikleri stratejilere ilişkin görüşleri yüz yüze mülakatlar aracılığıyla toplanmıştır.

\subsubsection{Edremit'in Turizm Potansiyeli ve Yaşanan Değişimler}

Yapılan görüşme sonuçlarına göre, yerel işletmecilerin çoğunluğu Edremit'in bir turizm merkezi özelliğini yitirdiğini düşünmekte ve bir yerin turizm merkezi olabilmesi için yeterli altyapıya ve turizm çekiciliklerine sahip olması gerektiğini düşünmektedirler. Bununla birlikte, burayı bir turizm merkezi olarak gören katılımcılar da benzer şekilde Edremit'teki turizm altyapısının yeterli olmadığını ve turistik faaliyetlerin çeşidinin de benzer şekilde kısıtlı olduğunu ifade etmektedir.

"Evet, bir turizm merkezidir, ancak yeterli yatırımın yapılmaması cazibe merkezi olma özelliğini gölgede bırakmıştır" (Yi1).

"Turizm Merkezi olabilmesi için yaz ve kış turizmin olması gerekmektedir. Yeterreli tesis olmadığından turizm merkezi değil$\operatorname{dir}^{\prime \prime}$ (Yig)

Bununla birlikte, Edremit'in hangi özellikleri ile turizme konu olabileceği yönünde ifade edilen görüşlerin ortak noktasında ise; ilçenin sahil bandının, ulaşım kolaylığının, tarihi dokusunun, Akdamar Adası ve Akdamar Kilisesi gibi önemli turistik çekiciliğe sahip doğal ve kültürel değerlere yakın olması yer almaktadır. Bu noktada özellikle ulaşım ile ilgili olarak hem liman hem de havaalanına yakın bir noktada bulunmasının ilçeye önemli bir değer katthğı görülmektedir. Ancak, birçok işletmecinin yeni geliştirilebilecek alternatif turizm olanaklarına yönelik herhangi bir görüş belirtmemiş olması da ilginç ve önemli bir noktadır. Özellikle yeni çevre düzeni planında bazı alanların ekoturizm gelişim alanı olarak ifade edilmesine rağmen, yerel işletmelerin bundan çok da haberdar olmadıkları görülmektedir (Şekil 8). Örneğin, Dönemeç Deltası içerisinde bulunan Engil Sulak alanı birçok kuş türü ve diğer canlılar için önemli bir biyolojik rezerv alanı olmasına rağmen, şu an için bu konudaki farkındalık yeterli düzeyde değildir. Bu koruma alanın yakın çevresi özellikle kamp ve karavan alanının bulunduğu saha ekoturizm faaliyetleri için planlanmış bir turistik mekân konumundadır. Bu sahada aynı zamanda Urartular döneminden kalma Dilkaya Köyünün yakınlarında bulunan bir höyükte mevcuttur.

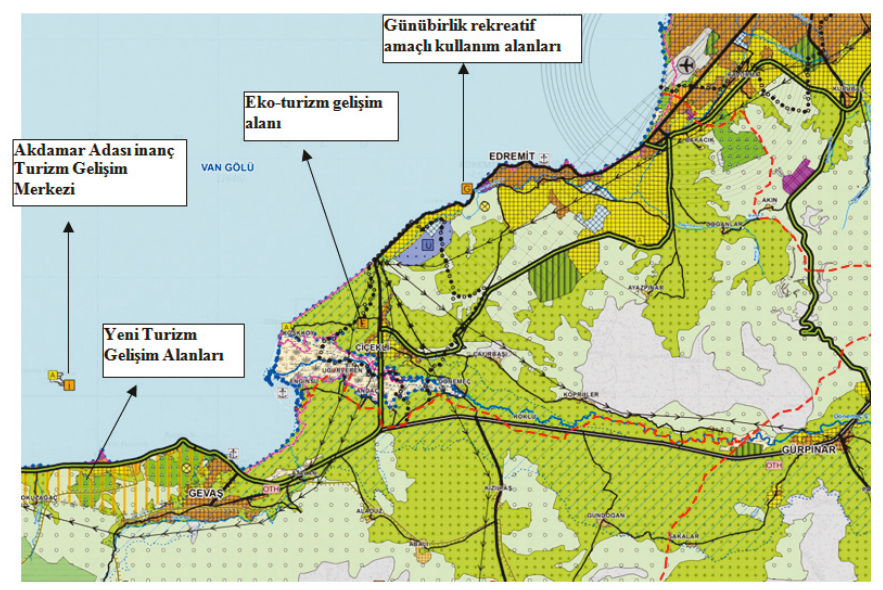

Şekil 8. Edremit ilçesine ait 1/100.000 ölçekli Çevre ve Düzen Planı Figure 8. A view of daily recreational areas in Edremit Province

Seyahat acentaları ile yapılan görüşmelerden, yerel işletmelere göre daha farklı ve uzmanlık içeren görüşlerin iletildiğini ve Edremit'in farklı yönlerine vurgu yaptıkları görülmektedir. Katlımcıların görüşlerine göre Edremit temelde iki farklı şekilde turizme konu olmaktadır. Bunlardan ilki, Van kent sakinlerinin sayfiye amaçlı kullanımından kaynaklanan rekreaktif amaçlı turizm, bir diğeri ise kentin doğal ve tarihi çekiciliklerinin yaratth̆̆ ve ulusal turizme 620 konu olan, çoğunlukla da Van kent merkezinde konaklama yapılması şeklinde gerçekleşen 621 turizm hareketidir. İletilen görüşlere göre Edremit'in bağımsız bir destinasyon olarak da düşünülebileceği ancak Van ilinin diğer turizm öğeleri ile birlikte bütünleşik bir yapıda 623 değerlendirmenin daha doğru olacağı yönündedir. Sunulan imkanlar, hizmetler Edremit 624 özelinde yeterli olmayabilir. Edremit'ten, gelişime açık bir yapıya sahip olduğu ve sürekli 625 geliştiği için ve karma bir yapı içerisinde (Akdamar Adası, Hoşap Kalesi, Muradiye Şelalesi, 626 Van Kalesi, Urartu Müzesi vb.) önemli bir turizm merkezi olarak söz edilebilir. Bunlarla 627 birlikte bir acentemiz tarafindan, her zaman somut veya somut olmayan kültürel özelliklerinin yeterli çekicilik oluşturamayabileceğine vurgu yapılarak "Van'a gelen turistlere 629 mutlaka Edremit'ten gün batımı izlettirmek için program düzenlediklerinden" bahsetmiştir. 630 "Bir gün batımını seyrettirmek bile birçok insanın o bölgeyi ziyaret etmesine neden 631 olabiliyor."Buradan hareketle yeni ve farklı yaklaşımlarla yeni turizm çekicilikleri oluşturmak için çaba göstermek gerektiği düşünülmektedir. Bu çerçevede, Adger'in (2000) de vurguladığı üzere özellikle rezilyans toplumların sahip olması gereken hem işbirliği hem de ekonomik çeşitlilik noktasında yerel halk ve turizm işletmelerinin ürün çeşitliliğini artırmaları gerektiğidir.

\subsubsection{Edremit'in turizm potansiyelinde meydana gelen deği- şimler: Firsatlar ve engeller}

Esnafin turizme yönelik değişimi yorumlarken özellikle iki nokta üzerinde durduğu görülmektedir. Bunlardan bir tanesi alt yapıda meydana gelen değişimler diğeri ise turist profilinde mey- 
dana gelen değişim şeklindedir. Önceki bölümde de ifade edildiği gibi Edremit belediyesi tarafindan son yıllarda (2016 yılı itibari ile) özellikle altyapıya yönelik önemli yatırımlar yapılmıştır. Bunun en somut örneklerinden bir tanesi, Edremit sahil bandının sosyal donatı alanı olarak düzenlenmesi ve buradaki ilgili kanunlara aykırı yapılaşmış derme çatma barakaların ve işyerlerinin sahil bandından temizlenmesi şeklinde olmuştur (Şekil 9 ve Şekil 10). Esnafin genel anlamda bu değişim ve dönüşümlere yönelik tepkisinin olumlu olduğu görülmektedir ve bu gelişmelerin Edremit için önemli bir firsat olduğu düşünülmektedir.

"Son 3 (üç) yılda Kayyumla birlikte Belediyeciliğin devlet eliyle yarattı̆ı pozitif etki turizme katkıda bulundu." (Yi3)

"Son dönem yapılan çalışmalar Edremit'i cazip kılmaya başladı. Etkinlik ve festivallerin düzenlenmesi turizmi etkiledi". (Yi10)
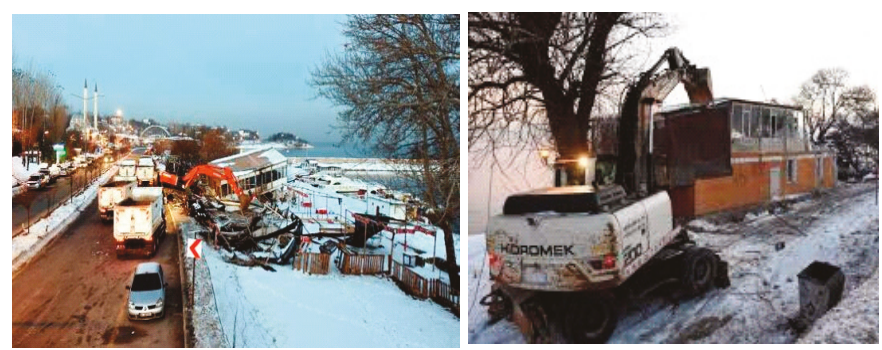

Şekil 9. Edremit sahil bandında kaçak yapılara yapılan operasyon görüntüsü. Figure 9. A view of the municipality's demolishing illegal facilities nearby the coastal area
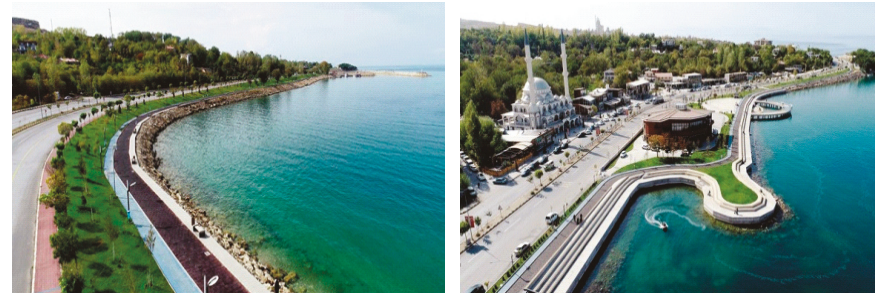

Şekil 10. Edremit sahil bandının yapılan iyileştirmeler den sonraki görünümü Figure 10. A view of Edremit coastline after the redevelopment in the area.

Seyahat Acente temsilcileri ise Edremit'te son zamanlarda yapılan altyapı çalışmalarını olumlu karşıladıklarını ve yapılan çaIışmaların turizmin gelişim sürecine olumlu katkılar sağlayacağını ifade etmektedirler. Yapılan yorumlar bu çalışmalar ile özellikle 2011 yılında yaşanan depremin etkilerinin de hızlı bir şekilde bertaraf edildiğini göstermektedir.

"Son 2 yıldan önce atıl durumda olan bir Edremit var iken şimdi yeni bir Edremit var. Çöpten arınmış, yapılaşmaya önem verilmiş, altyapı geliştirilmiş bir Edremit'ten bahsedebiliyoruz. Insanlar özellikle tarihi yapıyı veya atalarının yaşadığı toprakları gezip görmek istediklerinden burası daha da bir önem taşıyor. 90'lı yıllardan itibaren önemli bir güneş turizmi merkezi haline dönüştü." (S6)

Buna ek olarak meydana gelen değişimler noktasında katılımcıların gözlemlerinin en önemlilerinden bir tanesi de Few (2014) tarafindan da ifade edildiği gibi önemli turist gelen pazarların kaybedilmesidir. Bu çerçevede yerel esnafinda vurguladığı hususlardan biri bölgeye gelen turist profilinde meydan gelen değişimdir. Esnaf, artık Batılı gelişmiş ülkelerden gelen yabancı turistin bölgeyi tercih etmediğini, geçmişte özellikle 1990 'I yıllarda Avrupa'dan çok fazla turistin bölgeye geldiğini, evlerinin odalarını ve bahçelerini kamp kurmak ve karavanların park edilmesi için onlara kiraya verdiklerini ifade etmektedirler. Buna rağmen, günümüzde turist profilinin tamamen yerli turistten ve son birkaç yılda az sayıda gelen İranlı turistlerden oluştuğunu vurgulamaktadırlar.

"Iş̧letmeler açısından bir deneyim söz konusu olmadı. Yerli turist için önemli gelişmeler yaşandı, ama yabancı turist için önemli bir değişim yaşanmadı. Benim bu konudaki geçmişteki deneyimlerimden hareketle şu şekildedir: yüz yerli turist geleceğine on tane yabancl turist gelsin. "(Y1)

Esnafin geçmişe yönelik özleminin temelinde turiste yönelik bir kalite beklentisiyle birlikte hem daha fazla döviz bırakan, hem de tutum ve davranışlarıyla daha nitelikli turist olduğu vurgulanmaktadır. Bu çerçevede, turist sayısındaki niceliksel bir değişim çoğu zaman nitelikle eş değer görülmediği ifade edilebilir.

"Yerli turist sayısındaki artış gözlemlediğim en önemli değiş̧im diyebilirim". (Yi4)

SA'nın turizmin değişimine ve gelişimine yönelik görüşlerine bakıldığında ise değişim sürecinde kendi gözlemlerinin daha çok altyapı ve ilgi anlamında olduğunu ifade etmektedirler. Buna ek olarak, İran ve Ermenistan pazarının alternatif olarak girmesi sonucunda yeni bir adaptasyon sürecinin başladığı görülmektedir.

"Biz başladığımız zaman iran halkı yoktu ama sonrasında iran halkından dolayı turlarımızı arttırdık." (SA3)

Turizmin yerel sosyal, kültürel ve doğal çevreye çeşitli etkileri olabilmektedir. Bu çerçevede, turizmle birlikte başlayan bir değişim ve dönüşüm olup olmadığına yönelik soruya birçok katlımcının yanıtı "olmadığı” yönündedir. Özellikle uzun yıllar turizmden kazanç sağlayan ve yabancı turistle yoğun bir şekilde etkileşim halinde bulunan esnafin yabancı turist özlemi çektiği görülmektedir. Bunun temel nedenini ise özellikle 2000'li yılların başında yabancı turist gelişleri aniden durmasıdır. Bu özlemin nedenini, sadece maddi anlamdaki kazanç değil, yabancı turistin özellikle yerel kültürün ve doğanın korunmasına da önemli katkılar sağlaması ve kendilerini daha rekabetçi kılması oluşturmaktadır. Gelişmiş ülkelerden gelen turistlerin özellikle konaklama için daha çok çadır kullanımı, karavan araçlarıyla seyahat etmeleri ve yerel halkın evlerini pansiyon olarak kullanma gibi eğilimlerde olmalarından dolayı doğanın sürdürülebilir kullanımı noktasında önemli bir örnek oluşturmuştur. Ayrıca, o dönem gelen turistlere daha iyi hizmet sunma amacıyla tesislerini daha modern hale getirme ve hizmet kalitesini artırma çabası içerisinde olan esnaf açısından da rekabet gücünü artırmıştır. Diğer taraftan, yerel esnafin iş yerlerinde daha temiz bir ortam oluşturmaları ve kalite odaklı olmaları da önemli beğeni kazanan hususlardan bir tanesidir. Örneğin, yerel İşletmecilerden bir tanesinin temizlik ve hijyen konusunda geçmişte bölgeye gelen Fransız turistlerin ülkelerine döndükleri zamanlarda kendilerine teşekkür mektupları gönderdiğini bunun da kendilerini bu konuda ilerletme noktasında teşvik ve memnun ettiğini ifade etmektedir.

"Hayır yaşanmadı, çünkü 2002 yılından sonra turist gelmediği için değişim yaşanmadı. 1990'larda inanılmaz bir turist yoğunluğu vardı." (Yi1)

"Hayır maalesef yaşanmıyor, çünkü 15 yıl önce yabancı turist geliyordu ama artık gelmiyor. Bu nedenle bir değişim yaşanmı- 
yor." (Yi2)

Seyahat acentaları ise bu soruya yanıt verirken bazı değişimler gözlemlediklerini belirtmektedirler. Bu anlamda, farklı kültürlerin birbiriyle girdikleri etkileşim sonucunda birbirlerini tanıma ve deneyimleme noktasında önemli bir katkısının olduğunu belirtmektedirler. Buna rağmen, bazı SA'nin vurguladığı diğer önemli bir husus ise özellikle turlar aracılığıyla gelen turistlerin ilgi alanlarının alışveriş ve eğlence olduğu için yerel halk ile aralarında çok fazla bir kültürel etkileşim yaşanmadığı yönündedir.

"Turizm para harcamadan bazı kültürleri almanın en kolay yolu olmaya başladı. Artık belli şeyler için organizasyon bile yapıyoruz. Turistin isteklerine göre yerel halk kendisini geliştiriyor ve hizmetini ona göre yapıyor." (S6)

Yabancı turistlerin bölgeye gelmemesinin önündeki engeller noktasında ise görüşleri sorulan esnaf özellikle bölgede yaşanan siyasi istikrarsızlık, terör olayları, basın ve sosyal medya aracılığıyla oluşan olumsuz haberlerin önemli etkisinin olduğuna vurgu yapmaktadırlar.

"Maddi ve manevi anlamda ciddi değişime neden oldular. Avrupalı turistin gelmeme nedeni ise bana göre terör olayları ve bürokratik engeller." (Yi2)

"iç karışıklıklardan dolayı, eskiden gelen Japon turistler artik gelmiyor. Iki yıldır yerli turist sayısı artınca doğuya bakış açısında değişim oldu." (Yỉ)

Yabancı turistin gelmemesi noktasında farklı görüşler de ortaya konulmuştur. Bu görüşlerden biri esnafin turiste davranışının önemli bir yeri olduğudur. Bir diğer farklı görüş ise illçenin araştırmanın yapıldığı dönemdeki yerel yöneticisine aittir ve geçmişte kente gelen Avrupalı yabancı turistlerin Dünya'daki global hümanizma hareketi çerçevesinde ortaya çıkan "hippi" akımıyla birlikte özellikle karavan, minibüs veya bireysel yolculuklar aracılığıyla bölgeyi gezip görmek istemelerinden kaynakladığını ifade etmektedir.

Amir vd. (2015) tarafindan da vurgulandığı üzere, toplumsal rezilyansın uygulanması sürecindeki en önemli stratejilerden bir tanesi katılımcı ve işbirlikçi yönetim ve iletişim ağının oluşturulmasıdır. Buna rağmen, katılımcı esnaflar tarafindan belirtilen bazı hususlar çerçevesinde Edremit'te turizmin gelişiminin önünde çeşitli engeller olduğu anlaşılmaktadır. Bunların en başında bürokratik konunun geldiği ifade edilmiştir. Bu anlamda vurgulanan en önemli konu ise özellikle sahil kesiminin kamu kuruluşlarının tesisleri tarafindan doldurulduğu ve bu nedenle kıyı sahil koruma kanunun tam olarak uygulanamadığıdır. Bu çerçevede özellikle iyi bir imar planının olmaması nedeniyle çevre ve doğayı koruma noktasında önemli eksiklerin ortaya çıktı̆ı ve ilçenin zaman içerisinde betonlaşthğına dikkat çekilmektedir. Bu durum son yıllarda ortaya çıkan çevre düzeni planında da rahatlıkla görülmektedir. Sahil kesimi ve hemen arkasında yer alan 1.sınıf tarım arazilerinin yapılaşmaya izin verilmesiyle birlikte tarih öncesi dönemde de özellikle Urartular tarafindan yapılan su kanalları vasıtasıyla önemli bir meyve yetiştiricilik merkezi olan ve bahçeleriyle ün kazanan "Yeşil Edremit" sloganının yerine, artk toplu konut alanlarının yoğunlaştı̆̆ı bir yerleşim merkezine dönüştüğü görülmektedir.

"Bürokrasi engelleri, Edremit sahil şeridinin kamu kuruluşlarınca kullanılması."(Yi1)

"Çevreyi ve tabiat koruma da özensizlik, özel tesislere izin ve- rilmemesi, turizme yönelik tesislerin yeterli olmaması." (Yi5)

"Yatırımların eksik olmasından kaynaklı turizm gelişmiyor. Turizmin gelişmesi için öncülük yapılmıyor." (Yi7)

SA'nın görüşlerinin genelinde bakıldığında ise Edremit'te turizmin gelişmesinin önünde önemli bir engel olmadığı, tam aksine önemli kültürel ve doğal zenginliklerinin bulunduğunu vurgulanmaktadır. Ancak, yine de bazı SA tarafindan altyapıdaki bazı eksikliklerin giderilmesi gerektiği ifade edilmektedir.

“Engel görmüyorum. Doğa, güneş, göl vb. şeyler için gelebilecek onlarca insan var. Ancak geliştirilmesi gereken şeyler var. Örneğin spor turizmi için tesislerin yapılması, karavanlar için alt yapı yapılması gibi." (SA6)

Bununla birlikte bütün esnaflar arasında bir esnaf, geçmişte buranın terör olayları nedeniyle güvenlik bölgesi ilan edilmesi nedeniyle basında ve medyada çıkan haberlerin İlçenin imajını olumsuz anlamda zedelediğini ve bu haberlerin İlçede turizmin gelişimine önemli bir engel oluşturduğunu vurgulamıştır.

"Bölgenin önceki dönemde OHAL Bölgesi olması engeldir." (Yi9)

SA'nın bu konuda daha farklı görüşleri olduğu görülmektedir. Bu konuda öncelikle güvenlik endişesi nedeniyle daha önce bölgeye gelmeyenlerin, geldikleri zaman karşılaştıkları tablo karşısında geçmiş önyargılarının tümüyle yıkıldığını vurguladılar. Hatta turistlerin bölgenin doğal güzellikleri ve yerel halkın misafirperverliğine ilişkin deneyimlerini ve hissettiklerini yakın çevrelerine olumlu anlamda aktaracaklarını ve bölgeye gelmeleri noktasında önerileri olacağını ilettiler. Bu durum, rezilyans teori için iyi bir uygulama örneği oluşturmaktadır. Bölgede hizmet veren turizm pazarlayıcılarının birlikte hareket ederek sorunlarla baş etme anlamında bölgenin güçlü yönlerini öne çıkartth̆̆ını ve zayıf yönleri olan güvenlik sorunu ve olumsuz algının yıkılması anlamında da işbirliği yapmalarının önemini göstermektedir.

"Doğuya karşı bakış açıları olumlu yönde değişip ön yargıları kırıldığını düşünüyorum". (SA2)

"Van'daki olumsuz etkenlerden dolayı olumsuz görüşlere sahipken turistlerin geldiklerinde öyle olmadığını gördüler." (SA5)

\subsubsection{Adaptasyon}

Adaptasyon kapasitenin artırılması rezilyans ortamının oluşturulması için en önemli yaklaşımlardan bir tanesini oluşturmaktadır. Yerel esnafin ortaya çıkan yeni süreçlere nasıl adapte oldukları veya adaptasyon noktasında nelerin gerekli olduğuna yönelik görüşleri noktasında farklı görüşler ortaya çıkmaktadır. Yerel esnaf öncelikle yerel halkın daha fazla bilinçlendirilmesi gerektiğini, yabancı dil bilgisi olan nitelikli personel ihtiyacı olduğunu, devlet tarafindan yeni teşviklerin sunulması gerektiğini ve hedef turist pazarının değişimi gibi yeni stratejilerin ortaya konulması gerektiğini ifade etmişlerdir. Bu konuların birçoğu sosyal rezilyans için önemli stratejilerin başında gelmektedir.

Bu çerçevede Lew (2014) tarafindan da vurgulandığı gibi yerel girişimcilerin meydana gelen olumsuz durumlara karşı geliştirdikleri reflekslerin birçoğu çeşitlenme, kalite artışı, farklı ürünlerle yeni pazarlara yönelmek şeklindedir. Bu anlamda, Edremit'teki yerel esnafin Batılı yabancı turist pazarının yok olmasıyla birlikte İranlılara yönelik bir destinasyon oluşturma çabası içerisine girdikleri görülmektedir. Bu çerçevede, bazı esnaflar İranlıların gelişini olumlu anlamda değerlendirirken ba- 
zıları ise olumsuz bir gelişme olarak görmektedirler. Örneğin, bir katlımcı İranlıların Van'a yönelmesi sonucunda kentin bir Ortadoğululaşma eğilimi içerine girdiğine vurgu yapmaktadır.

"Siyasi olaylardan kaynaklı bölgeye gelen özellikle iranlı turistlerden kaynaklı Van'da Ortadoğululaşma oluştu." (Yi3)

"Yatırımlarımızı daha çok Batılı turiste göre yapmıştık ve bu çerçevede turizmin yoğun olduğu dönemlerde ciddi yatırımlar yaptik. Ancak şu an turist olmadığından yatırımlarımız boşa çıkt, çünkü Iranlı turistler yeteri kadar para harcamıyorlar" (Yi1).

Bu duruma rağmen, birçok esnafin ise bu gelişmeden memnun olarak yeni bir adaptasyon süreci başlatth̆̆ ve bu yeni sürece daha iyi bir şekilde hazırlandıkları, işletme kapasitelerini artırarak adapte olmaya çalıştıkları görülmektedir.

"Özellikle Iranlı turistlerin artısı bizi işletmemizi büyütmeye yöneltti." (Yi11)

"Acentalarla çalışmaya başladık. Özellikle Iranlı turistlerin yoğun olduğu dönemde fiyat indirimine gittik."(E2)

Konaklama işletmeleri bağlamında bakıldığında ise işletmelerin özellikle yerli ve yabancı turistlerin ihtiyacına yönelik olarak, işletmelerinde kalite artırma ve markalaşma çalışmalarına önem verdikleri görülmektedir. Örneğin, son zamanlarda uluslararası açılan bir otel zinciri de bunun en temel göstergelerinden bir tanesidir.

"Yerel bir işletme olarak hizmet veren Rescate, 5 yıldızlı uluslararası bir otel zincirine dönüşmüştür." (Yi3)

"Özellikle Iranlı turistlerin yoğun olarak gelmesi bizi yılda en az iki defa restorasyon yapmaya ve işletmede değişiklikler yapmaya sevk etti." (Yi7)

SA'nın da değişime karşı geliştirdikleri becerilerin güçlendiğini ve çeşitli değişimler uygulayarak karşılaşttkları zorlu durumlara karşı daha fazla hazırlıklı hale geldikleri görülmektedir. Bu çerçevede acentaların yerel işletmeler gibi yeni gelişen turist pazarlarına uygun değişim ve dönüşümlere yöneldikleri görülmektedir. Özellikle yerel turistin sayısının artması ve İran pazarının da açılmasıyla birlikte buna karşı bir refleks gösterdikleri görülmektedir. Buna rağmen, örneğin geçmişle önemli bir kültürel bağı olan bölgenin Ermenistan pazarının bu süreçte çok fazla gündeme gelmediği görülmektedir. Örneğin;

"Biz başladığımız zaman iran halkı yoktu ama sonrasında iran halkından dolayı turlarımızı arttirdık." (SA3).

"Rehberlik olarak açtığımı işletmemizi Seyahat Acenteliğine çevirdik. Elde olmayan nedenler olumsuz etkilediyse de biz bunu olumlu yöne çevirmek için çalıştk. Avrupalı turist gelmeyince yerli turiste yöneldik. Turlarımızı çoğaltarak kendimizi geliştirmeye çalıştı. Şimdilerde ise Iranlı turistlere yönelik çalışmalar yapıyoruz. Turizm değişken bir yapıya sahip olduğundan ayak uydurmaya çalışıyoruz". (SA6)

Edremit'te turizm faaliyetlerinin iyileştirilmesi için katılımcıların vurguladığı hususların başında sosyal ve kültürel etkinliklerin yapılması gerektiğidir. Katılımcılar bu anlamda Van Gevaş ilıçesinde 2018 yılında düzenlenen ulusal müzik festivali "Gezginfest" ve benzeri organizasyonların düzenlenmesi gerektiğini belirtmişleridir. Gezginfest'2e 2018 yılında hem yerel hem de bölgedeki diğer illerden hatta İran'dan yüksek bir katılım gerçekleşmiştir. Ancak, aynı etkinliğin 2019 yılında tekrar edilme sine organizasyon komitesinin festival ile ilgili güvenlik ve diğer bazı konularda yeterince sorumluluk üstlenmediği için izin verilmemiştir. Bu gerekçelerin yanı sıra kentteki bazı STK'larında olumsuz görüş bildirmelerinin de festivalin düzenlenmemesinde etkili olduğu görüşü kentte konuşulmuştur. Bu STK'ların görüşleri görsel/yazılı medya ve billboardlar aracılığı ile yansıtılmış ve ayrıca festivalin iptali için basın açıklamaları yapılmıştır. (Şekil 11). Bu görüşlerin aksine olan ifadelerde sosyal medyada uzun süre paylaşılmış ancak festival iptal edilmiştir. Bu iptale rağmen, katılımcıların birçoğu bu tarz festivallerin hem kente hem de Edremit gibi konaklama ve yiyecek-içecek tesislerinin yoğun olarak bulunduğu illçeler'de turizm işletmelerine önemli katkılar sunabileceğini ifade etmektedirler. 2018 yılında Gevaş ilçesinde düzenlenen ve 3 günde 55 - 60 bin kişinin katıldığı tahmin edilen Gezginfest Festivali'nin Gevaş illçesinin yanı sıra Edremit ilçesine de ciddi anlamda hareket kazandırdığı belirtilmiştir. Yine, esnaflar 3 günlük süre zarfinda işletmelerinin önemli kâr elde ettiklerini ifade etmişlerdir. Bu da özellikle rezilyans teori çerçevesinde yerel işletmelerin gelişen ve değişen olumsuz durumlara karşı iyi bir refleks göstermesi noktasında kendilerinin adaptasyon becerilerini geliştirebileceğini göstermektedir. Turizmin bu çerçevede sezonluk değil, yıl boyuna yayılan bir olgu haline getirilmesi gerektiği noktasında görüşler ifade ettikleri görülmektedir.

"Altyapı sorunları giderilmeli, yatırımların yapılması, yemek kültürü tanıtımalı ve festivaller düzenlenmeli" (Yi11)

"Sezonluk turizm merkezi olmamalı, acentalara destek verilmeli, turistik faaliyetlerin arttırılması gerekmektedir." (Yi7)

"Devlet eliyle yatırımların yapılası, sezonluk turizm merkezi olmamalı." (Yi9)

"Turistik tesisler yapılmalı, sahil bandının tamamı turizme açılmalı, cazibe merkezi haline getirilmeli(Yi1)

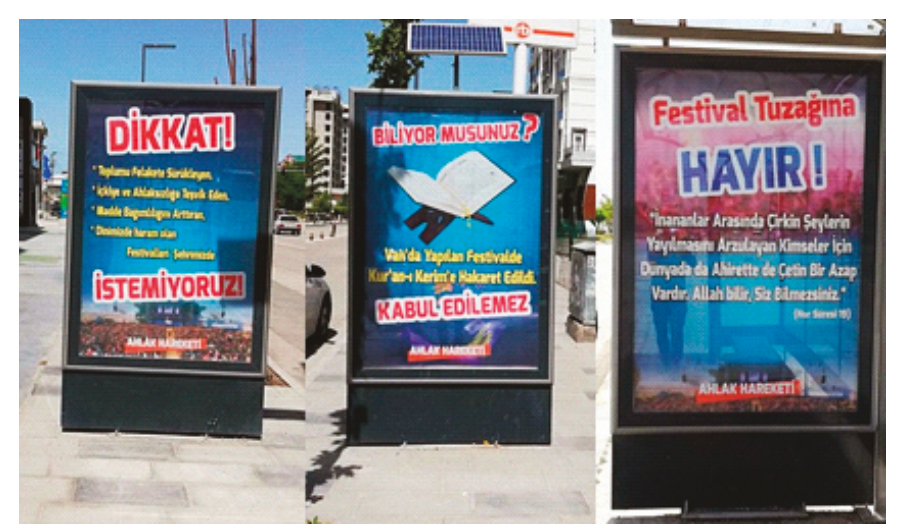

Şekil 11. Van kentindeki Bilboard'lardaki Gezginfest'in yapılmasına karşı çıkan ilanlar (Haziran 2019)

Figure 11. A view of announcements including opposite views against the organization of Gezginfest on the street billboards in Van city centre (June 2019)

Bu konuda, SA'da sosyal ve kültürel etkinliklerin kent ve turist arasında kültürel etkileşimi sağlamak konusunda önemli bir fonksiyonu olduğunu ve Edremit'in bir turistik destinasyon olması noktasında sosyal ve kültürel etkinliklerin geliştirilmesi gerektirdiğini vurgulanmaktadır.

"Evet yaşanıyor. En büyük örneğini geçen sene yapılan festivale gelen farklı yapıdaki insanlarla Vanlı insanlar arasında gördük." (SA1) 
"Bu etkileşimin yaşanabilmesi için kendi kültürel yapımızı süürekli sergilememiz gerekiyor. Bu anlamda seyahat acentelerine büyük görev düşüyor. Kültürel değişimlerin yaşanabilmesi için da halk olarak olanakların sağlanması gerekiyor. Örneğin, gelen turist aile olarak denize girmek istiyorsa buna imkân tanınmalıdır". (SA6)

Diğer taraftan kentin ve ilçenin altyapı eksiklerinden kaynaklı olarak doğal çevrenin yeterince korunamamasının turizmi olumsuz etkiyebileceği belirtiliyor. Katlımcılar tarafindan, Edremit'in cazibe merkezi olmasında en önemli etkenlerden biri olan Van Gölünün ve yakınında bulunan sulak alanların korumasının ve korunma ile ilgili politikaların acilen üretilmesinin gerektiğine yönelik vurgular özellikle yapılmaktadır. Örneğin;

"Altyapının düzenlenmesi, Van gölünün korunması, tesislerin artirılarak cazip hale getirilmesi" (Yi6)

"Altyapı, doğalgaz, arıtma ve elektrik problemlerinin çözülmesi gerekiyor. Devlet teşviklerinin artması, girişimcilerin desteklemesi, tesis sayısı arttırılmalı." (Yi2)

Edremit'te yer alan işletmeciler özellikle altyapı problemlerinden yakınmaktadırlar. En önemli sorunlardan biri ise kanalizasyon altyapısının olmaması olarak belirtilmiştir. Edremit'te sahil kesimine yakın olan işletmelerde kanalizasyon ve altyapı hizmeti olmadığından işletmeler kanalizasyon atıklarını kuyular (foseptik) ile çözmekte ve bu kuyular ancak vidanjörlerle boşalthlabilmektedir. Katilımcılar, bu durumun turizm merkezi olma yolunda olan Edremit'te ciddi bir problem olduğu belirtilmişlerdir.

Edremit sahil kesiminde yer alan işletmelere altyapı yetersizliği nedeni ile doğalgaz verilememesi, esnafları işletme maliyetlerini oldukça yükselten farklı ısıtma yöntemleri arayışına sevk etmiştir. Bu da turizm merkezi olma yolunda olan Edremit'te ciddi bir problem oluşturmuş esnaf açısından maliyetleri yükseltmiş ve hizmet kalitesini oldukça etkilemiştir.

\section{Sonuçlar ve Öneriler}

Van’ın Edremit ilçesindeki turizmin gelişimine, değişimine ve planlanmasına odaklanan bu çalışma sektör temsilcileri aracıIığıyla değerlendirilmiştir. Elde edilen bulgulara göre 1990'lı yıllarda Van İlinde ve Edremit ilçesinde ciddi bir turist potansiyeli olduğu tespit edilmiştir. Bu yıllarda gelen turistlerin genellikle 3 (üç) günlük turlarla geldikleri tespit edilmiştir. Bunların yanı sıra karavanlarıyla gelenlerin yanı sıra bireysel olarak gelerek çadırlarda kamp kuranların oldukları belirtilmiştir. Avrupalı turistlerin yoğun olarak geldiği bu dönemde turizm faaliyetlerinin çok hızlı bir şekilde geliştiği vurgulanmıştır. Yine, o dönemde esnafların turistlerin beklentileri yönünde işletmelerini yenilemeye/düzenlemeye gittikleri ve Van ili ve kültürünü tanıtımı için yoğun bir çaba içerisine girdikleri ifade edilmiştir. Buna rağmen, yaşanan jeo-politik problemlerden kaynaklı olarak yapılan güvenliğe ilişkin denetim ve güzergah kontrollerinin artmasından dolayı turistlerin güvenlik kaygısı taşıdığı ve bunu sık sık dile getirdikleri ifade edilmektedir. Bununla beraber, turizm kültürünün tam oturmamış olması sebebiyle turistlerin konaklama, yeme-içme ve hediyelik eşya alımı gibi durumlarda uygulanan fiyat standartsızlığı Avrupalı turistlerin Van turizm faaliyetlerine katılmama sebepleri arasında izah edilmiştir.
Yerel toplulukların rezilyans kapasitelerinin geliştirilmesinde en önemli stratejilerinden bir tanesinin yerel ekonomik kaynakların çeşitlendirilmesi ve alternatif kaynakların turizm faaliyetlerinde ortaya konulabilmesi olduğu literatürde vurgulanmaktadır (Adger, 2000; Becker, 2013, Amir vd. 2015). Buna rağmen, saha çalışmasından elde edilen bulgular çerçevesinde bölgenin kültürel mirasına dayalı yerel kaynakların turizm faaliyetlerinde kullanılma oranının giderek düştüğü görülmüştür. Son yıllarda turizm faaliyetlerinde görülen trendin yerel kültürleri tanımaya yönelik olduğu bilinmektedir. Oysa bölgemizde somut ve somut olmayan kültürel değerlerin deneyimlenmesine yönelik olarak yürütülecek pazarlama stratejilerinin -niş pazarlama gibi- yeterince kullanılamadığı ve desteklenmediği görülmektedir.

Edremit'te bulunan esnafin; genel anlamda turist algısının değiştiği Avrupalı turistlerden ümitlerini kestikleri bunun yerine yakın olması ve ziyaretçi sayısının çok olması nedeniyle İranlı turistler ve yerli turistlere yöneldikleri tespit edilmiştir. Esnafin bunun yanında İranlı ve yerli turistleri baz alarak işletmelerinde değişim ve onarım yaptıkları; eğlence kültürü, yemek kültürü ve müziklerde bu yönlü değişimler yaptıkları tespit edilmiştir. Ancak bu durumun işletmecileri çok tatmin etmediği gözlemlenmiştir. Avrupalı turistlerin Edremit turizmine katılmalarının ve bunun sürdürülebilir hale getirilmesinin kendilerine daha çok katkı sağlayacağı görüşünü bildirmişlerdir.

Edremit'te konaklamanın yerli - yabancı turist açısından ciddi bir problem olduğu ve otellerin hizmet kalitesinin istenilen seviyede olmadığı tespit edilmiştir. Turizm sektörünün en önemli ayağı olan konaklama tesislerinin kalitesinin turistler açısından önemi tartışımazdır. Edremit ilçesi turizm açısından en gözde ilçe olmasına rağmen konaklama hizmeti sunan işletmelerin yetersizliği turizmin gelişmesinde büyük bir sorun teşkil etmektedir. Katılımcılar, tüm yıl boyunca konaklama hizmeti verecek olan işletmelerin varlığı ile Edremit turizminin sadece yaz mevsimi ile sınırlanmayacağını, turizm faaliyetlerinin dört mevsim sürdürülebileceğini ve konaklama kalitesinin artmasının ancak yabancı turistlerin gelmesiyle birlikte yaşanacak hareketlilik ve sıcak parayla mümkün olabileceğini belirtilmişlerdir.

Adger (2000) tarafindan da ifade edildiği üzere sosyal anlamda rezilyansın oluşması sürecinde çeşitli engellerin olması, yerel toplumlarda genel bir ortak anlayışın oluşması sürecinde engel şeklinde ortaya çıkabilmektedir. Bu anlamda, Van illinde yaşanan depremden sonra özellikle Edremit'te yapılan TOKi Konutlarına ciddi bir insan göçü yaşanmış ve adeta yeni bir merkez kurulmuştur. Ancak TOKi Konutlarına giden araçların, Edremit merkezden geçmemesi ve güzergâhları belirlenirken Edremit merkezinin gelişmesi ve cazip hale gelmesi ilkesi göz ardı edildiğinden gerek esnaflar açısından gerekse Edremit açısından ciddi bir problem oluşturmuştur. Bunun yanında Edremit'te bulunan kamu kurumlarının ilçe merkezinden alınarak TOKi'ye taşınması özelde esnaflar için, genelde turizm merkezi olma yolunda olan Edremit'te olumsuz bir durum yaşanmasına neden olmuştur. Edremit ilçe merkezinin daha işlevsel hale gelmesi için bundan sonra yapılacak olan değişikliklerde ilçe merkezinin dikkate alınması gerektiği görüşü işletmelerin ortak düşüncesi olarak belirtilmiştir.

Sürdürülebilir turizm faaliyetlerinin ortaya çıkmasında, özellik- 
le toplumsal tabanlı turizmin sosyo-ekolojik rezilyans ile arasında önemli bir ilişki olduğu ve karmaşık yapıların çözümlenmesinde etkili bir araç olduğu Ruiz-Ballesteros (2011) tarafindan da ifade edilmektedir. Edremit'te daha önce kıyı ve sahil şeridinin, ruhsatsız ve görüntü kirliliği yaratan işletmeler tarafindan kullanılması ve insanların sahil şeridinden yararlanamamasının ciddi bir problem oluşturduğu tespit edilmiştir. Sonrasında 2017 yılında Belediye tarafindan bu işletmelerin temizlenmesi bu alanlarda yürüyüş yolları yapılması, çevre düzenlemesi yapılması, parkların, piknik alanlarının ve tesislerin yapılması hem esnaflar açısından hem de turizm merkezi olma yolunda Edremit'te ciddi bir gelişmeye ve değişmeye neden olmuştur. Yapılan tesislerin ve yeşil alanların varlığı, Edremit'te pozitif bir etki yaratarak insanların buraları kullanma sıklıklarında artı̧̧ olduğu ve oldukça ilgi gördüğü belirtilmiştir. Ancak, bu bağlamda, Edremit turizm faaliyetlerinin günü-birlik olduğu ve bu yönde ilerlediği kalıcı turizm faaliyetleri için daha fazla yatırım yapılması gerektiği tespit edilmiştir.

Becken (2013) tarafindan bir turistik destinasyonda çeşitli engelleyici faktörler ortaya çıkabileceği belirtilmiştir. Bunlar arasında günümüzde özellikle en önemli çevresel sorunlardan bir tanesi olan iklim ve hava şartlarının değişimi nedeniyle gelen turist sayısının azaldığı için yerel işletmelerin turizm kaynaklı gelirlerinin azalmasına neden olabilmektedir (Coghlan ve Prideaux, 2009). Van ilinin coğrafi konumundan ve ikliminden kaynaklı; yaz ayının kısa sürmesi fakat kışların uzun ve sert geçmesinden kaynaklı, genelde Van'da özelde Edremit'te turizmin, 3-4 ayla sınırlı kalmasına neden olmuş, sonbahar ve kış aylarında esnafların ciddi bir mağduriyet yaşadıkları tespit edilmiştir. Yaşanan bu mevsimsel turizmin etkisinin azaltılması için sonbahar ve kış aylarına dönük Edremit'te çeşitli faaliyetlerin yapılması ve turizm açısından cazip hale getirilmesi gerektiği belirtilmiştir. Özellikle İklim değişimine bağlı olarak Gevaş ilçesinde kurulu olan Abalı Kayak tesisinde de yeterli kar birikmemesine bağlı olarak tesisin verimli olarak kullanılamadığı da bu sonuçlardan bir tanesidir.

Rezilyans teorisinin ortaya çıkarttı̆̆ en önemli stratejilerden bir tanesi de yerelde geniş tabanlı işbirliklerine olan ihtiyaç ve bunların gerçekleştirilmesi durumunda toplumsal rezilyans kapasitesinin artırılabileceğidir (Ruiz-Ballesteros, 2011; Berkes ve Rose, 2013; Amir vd. 2015). Edremit'in cazibe merkezi olabilmesi için özellikle siyasilerin, bürokrasinin ve varlıklı işadamlarının bu konuda duyarlılık göstermeleri ve girişimde bulunmaları gerektiği belirtilmiştir. İşletme sahipleri Edremit'in turizm açısından cazibe merkezi olması yolunda kendi imkânlarının yetersiz olduğunu, devlet eliyle kendilerine teşvik ve kredi desteğinin verilmesi gerektiğini belirtilmişlerdir. Bec vd. (2016) tarafindan da vurgulandığı üzere, yerel halkın nezdinde sosyal rezilyansın oluşması turizmin gelişmesi için ön koşullardan bir tanesidir. Bu bağlamda, yerel halk ve sivil toplum örgütleriyle birlikte yapılacak işbirlikleri ve planlamalar turizmin gelişiminde ve toplumun belirsizliklere karşı dirençlerinin artrılması noktasında önemli bir katkı sunabilecektir.

Son söz olarak, yapılan çalışma sonunda çok fazla tarihi, coğrafi ve kültürel yapıyı içerisinde barındıran Van ili Edremit İlçesinin destinasyon olarak gelişememesinin nedeni olarak yeterli altyapı, yatırım ve tanıtım desteği olmadığı paydaşlar tarafindan değerlendirilmiştir. Doğru turizm politikalarının geliştirilmesi, yeterli düzeyde alt ve üst yapı yatırımlarının ivedi olarak yapılması, farklı kesimlere hitap edecek tanıtım faaliyetlerinin il Kültür Turizm Müdürlüğü tarafindan yapılması, nitelikli turizm çalışanlarının istihdam edilmesi, yerel halka bu bağlamda seminerler verilmesi, kültürel miras konumundaki maddi ve manevi kaynakları koruma ve yaşatma faaliyetlerinin desteklenmesi halinde turizm destinasyonu olması yolunda Edremit'e büyük katkılar sağlayacağı öngörülmüştür. Aşağıda sunulan temel öneriler ortaya konulmuştur:

- Kültürel ve sanatsal festivallerin yapılması, özellikle Van Gölünün bu anlamda daha iyi kullanılması ve değerlendirilmesi öneriliyor. Van Gölünde yapılacak olan şenliklerin ve sportif aktivitelerin Edremit'i tanıtacağı ve oldukça cazip hale getireceği belirtilmiştir.

- Edremit'in önemli kültürel ve yerel değerlerinden olan; bahçe kültürü, üzüm bağları, erik, çiçek, yöresel yemekler vs. değerlerin ön plana çıkarılması ve bunların turizme açılmasına destek sağlanması gerektiği düşünülmektedir.

\section{Teşekkür/Acknowlegment}

Saha çalışmalarında bize yardımcı olan yükseklisans öğrencilerimiz Vedat Atay, Satiye Kaçmaz ve Novita ANGGRAHiNi'ye teşekkürü bir borç biliriz.

\section{Kaynakça}

Adger, W. N. (2000). Social and ecological resilience: are they related?. Progress in human geography, 24(3), 347-364. Alexander, D. E. (2013). Resilience and disaster risk reduction: an etymological journey. Natural hazards and earth system sciences, 13(11), 2707-2716.

Amir, A. F., Ghapar, A. A., Jamal, S. A., \& Ahmad, K. N. (2015). Sustainable tourism development: $A$ study on community resilience for rural tourism in Malaysia. Procedia-Social and Behavioral Sciences, $168,116-122$.

Aşur, F . (2017). Van Kenti Yakın Çevresi Kıyı Alanı Örneğinde Sulak Alanlar ve Görsel Peyzaj Kalite Değerlendirmesi. Türk Tarım ve Doğa Bilimleri Dergisi , 4 (4) , 506-515.

Bec, A., McLennan, C. L., \& Moyle, B. D. (2016). Community resilience to long-term tourism decline and rejuvenation: A literature review and conceptual model. Current Issues in Tourism, 19(5), 431-457.

Becken, S. (2013). Developing a framework for assessing resilience of tourism sub-systems to climatic factors. Annals of Tourism Research, 43, 506-528.

Beckett \& Raeder. (2017) Planning for Community Resilience in Michigan: A Comprehensive Handbook. LIAA; Beckett \& Raeder, Inc.; and the Michigan Association of Planning.

Berkes, F., \& Folke, C. (1994, August). Linking social and ecological systems for resilience and sustainability. In Workshop Property rights and the performance of natural Resource systems.

Berkes, F., Ross, H. (2013). Community resilience: towards an integrated approach. Soc. Nat. Resour. 26, 5-20.

Biggs, D. (2011). Understanding resilience in a vulnerable industry: the case of reef tourism in Australia. Ecology and society, 16(1).

Biggs, D., Hall, C., \& Stoeckl, N. (2012). The resilience of formal and informal enterprises to disasters: Reef tourism in Phuket Thailand. Journal of Sustainable Tourism, 20(5), 645-665.

Özden, A. T. (2012). Disaster, Memory and Culture: Distressing Attempts to Develop Disaster Culture in Turkey, The Newsleter,Disaster, Conflict and Social Crisis Research Network, Vol. 13, No. 48, pp. 9-14, August-November (www.dscrn.org).

Boluk, K. A., Cavaliere, C. T., \& Higgins-Desbiolles, F. (2019, baskıda). A critical framework for interrogating the United Nations Sustainable Development Goals 2030 Agenda in tourism. https://doi. 
org/10.1080/09669582.2019.1619748

Canadian Centre for Community Renewal. (2000). The community resilience manual. A resource for rural recovery and renewal. Port Alberni, Canada: Centre for Community Enterprise. http://communityrenewal.ca/sites/all/files/resource/P200_0.pdf (Erişim tarihi: 20 Ağustos 2019).

Coghlan, A., \& Prideaux, B. (2009). Welcome to the Wet Tropics: the importance of weather in reef tourism resilience. Current Issues in Tourism, 12(2), 89-104.

Dahles, H., \& Susilowati, T. P. (2015). Business resilience in times of growth and crisis. Annals of Tourism Research, 51, 34-50.

Farrell, B. H., \& Twining-Ward, L. (2004). Reconceptualizing tourism. Annals of tourism research, 31(2), 274-295.

Folke, C. (2006). Resilience: The emergence of a perspective for social-ecological systems analyses. Global environmental change, 16(3), 253-267.

Herman, A. (2015). Enchanting resilience: Relations of care and people-place connections in agriculture. Journal of Rural Studies, 42, 102-111.

Holladay, P. J., \& Powell, R. B. (2013). Resident perceptions of socialecological resilience and the sustainability of community-based tourism development in the Commonwealth of Dominica. Journal of Sustainable Tourism, 21(8), 1188-1211.

Holling, C.S., Schindler, D.W., Walker, B.W. and Roughgarden, J. (1994). Biodiversity in the functioning of ecosystems: An ecological primer and synthesis. In: Perrings, C, Maler, K.- G., Folke, C, Holling, C.S. and Jansson, B.-O. eds. Biodiversity Loss: Ecological and Economic Issues. Cambridge UP, Cambridge, UK.

Hung, H. C., Yang, C. Y., Chien, C. Y., \& Liu, Y. C. (2016). Building resilience: Mainstreaming community participation into integrated assessment of resilience to climatic hazards in metropolitan land use management. Land Use Policy, 50, 48-58.

Lambert, E., Hunter, C., Pierce, G. J., \& MacLeod, C. D. (2010). Sustainable whale-watching tourism and climate change: towards a framework of resilience. Journal of Sustainable Tourism, 18(3), 409-427.

Leap, B. (2018). Not a zero-sum game: inequalities and resilience in Sumner, Missouri, the Gooseless Goose Capital of the World. Gender, Place \& Culture, 25(2), 288-308.

Lerch, D.,(2017). The Community Resilience Reader : Essential Resources for an Era of Upheaval, Berkeley : Island Press.

Lew, A. A. (2014). Scale, change and resilience in community tourism planning. Tourism Geographies, 16(1), 14-22.

Maclean, K., Cuthill, M., \& Ross, H. (2014). Six attributes of social resilience. Journal of Environmental Planning and Management, 57(1), 144-156.

Munt, S. R. (2012). Journeys of resilience: The emotional geographies of refugee women. Gender, Place \& Culture, 19(5), 555-577.

Orchiston, C., Prayag, G., \& Brown, C. (2016). Organizational resilience in the tourism sector. Annals of Tourism Research, 56, 145-148.

Perrings, C. (1998). Introduction: resilience and sustainability. Environment and Development Economics, 3(2), 221-262.

Redman, C. L. and A. P. Kinzig. (2003). Resilience of past landscapes: resilience theory, society, and the longue durée. Conservation Ecology $7(1)$ : $14 . \quad$ [online] URL: http://www.consecol.org/vol7/iss1/art14/

Ruiz-Ballesteros, E. (2011). Social-ecological resilience and community-based tourism: an approach from Agua Blanca, Ecuador. Tourism Management, 32(3), 655-666.

Seçkin, Ş., \& Hasanoğlu, A. (2016). Çocukta rezilyans (2. baskı). İstanbul: Remzi Kitabevi.

Sterling, S. (2010). Learning for resilience, or the resilient learner? Towards a necessary reconciliation in a paradigm of sustainable education. Environmental Education Research, 16(5-6), 511-528.

Strickland-Munro, J. K., Allison, H. E., \& Moore, S. A. (2010). Using resilience concepts to investigate the impacts of protected area tourism on communities. Annals of Tourism Research, 37(2), 499-519.
Stokholm Rezilyans Araştırma Merkezi (2019), What is resilience? Erişim linki: https://www.stockholmresilience.org/research/research-news/2015-02-19-what-is-resilience.html (Erişim tarihi: 18 Kasım 2019)

T.C. Çevre ve Orman Bakanlığı (2006), Van Valiliği Çevre ve Orman Müdürlüğü, Van Ili Çevre Durum Raporu. (2006), http://www.vanherbaryum.yyu.edu.tr/vanre/vilcdr.pdf (Erişim tarihi: 18 Kasım 2019)

Tobin, G. A. (1999). Sustainability and community resilience: the holy grail of hazards planning?. Global Environmental Change Part B: Environmental Hazards, 1(1), 13-25.

Tsao, C. Y., \& Ni, C. C. (2016). Vulnerability, resilience, and the adaptive cycle in a crisis-prone tourism community. Tourism Geographies, 18(1), 80-105.

Tyrrell, T. J., \& Johnston, R. J. (2008). Tourism sustainability, resiliency and dynamics: Towards a more comprehensive perspective. Tourism and Hospitality Research, 8(1), 14-24.

United Nations World Tourism Organization (UNWTO). Tourism highlights. 2019 Edition. Madrid: UNWTO, 2019. https://www.eunwto.org/doi/pdf/10.18111/9789284421152. (Erişim Tarihi 24 Eylül 2019).

VANTSO (2018), 2018 Edremit İlçe Raporu. http://www.vantso.org.tr/u/files/5-FMY3071_5775.pdf (Erişim tarihi: 25 Eylül 2019)

Walker, B., Anderies, J., Kinzig, A., \& Ryan, P. (2006). Exploring resilience in social-ecological systems through comparative studies and theory development: introduction to the special issue. Ecology and Society, 11(1).

Walker, B., C. S. Holling, S. R. Carpenter, and A. Kinzig. (2004). Resilience, adaptability and transformability in social-ecological systems. Ecol. Society 9(2):5. http://www.ecologyandsociety.org/vol9/iss2/art5 (Erişim tarihi: 18 Eylül 2019).

Weichselgartner, J., \& Kelman, I. (2015). Geographies of resilience: Challenges and opportunities of a descriptive concept. Progress in Human Geography, 39(3), 249-267.

Welsh M (2013) Resilience and responsibility: Governing uncertainty in a complex world. The Geographical Journal. doi: 10.1111/geoj.12012.

Wilson, G. A. (2013). Community resilience, social memory and the post-2010 Christchurch ( $N$ ew Z ealand) earthquakes. Area, 45(2), 207-215.

\section{İnternet Kaynakları}

http://emlakansiklopedisi.com/wiki/toki-van-merkez-serefiye-basvurulari-bugun-basladi

https://i.pinimg.com/originals/e0/0c/9d/e00c9dcff533345d23e92cc2 9431b2bb.jpg

https://vanedremit.bel.tr/proje-5-mesire-alani.html

https://www.haberturk.com/van-haberleri/62053438-edremit-belediyesinden-ikinci-halk-plajivan-golunde-ilk-defa-parasailing-gosterisi

https://www.oncevatan.com.tr/yasam/deprem-konutlari-havadangoruntulendi-h14063.html

https://www.trthaber.com/haber/turkiye/van-edremitte-kamp-vekaravan-merkezi-acildi-384843.html

https://www.yeniemlak.com/toki-van-edremit-projesi-kura-sonuclari-belli-oldu-18182-tokihttps://onedio.com/haber/kaymakamlik-gezginfest-van-a-izin-vermedi-huzur-icinde-duzenlenmesi-icingerekli-sartlar-saglanamadi-875437

http://www.hurriyet.com.tr/edremit-sahilindeki-kacak-yapilara-safakoperas-40371313

https://www.haberler.com/edremit-sahilindeki-kacak-yapilara-safak9284292-haberi/

https://www.haberler.com/edremit-sahilindeki-kacak-yapilarasafak-9284292-haberi/ 